\title{
Systematic processes of land use/land cover change to identify relevant driving forces: Implications on water quality
}

\author{
Zara Teixeira *, Heliana Teixeira, João C. Marques \\ IMAR - Institute of Marine Research, c/o Department of Life Sciences, Faculty of Sciences and Technology, University of Coimbra, $3004-517$ Coimbra, Portugal
}

\section{H I G H L I G H T S}

- LULC and LULC changes are important drivers of water condition.

- We identified strong signals of systematic transitions.

- Consistency and magnitude of systematic transitions reveal processes of LULC change.

- Processes of LULC change reveal important drivers of water condition.

- Relevant drivers reveal potential pressures linked to the process of transition.

\section{A R T I C L E I N F O}

\section{Article history:}

Received 11 July 2013

Received in revised form 21 October 2013

Accepted 27 October 2013

Available online 6 December 2013

\section{Keywords:}

Water framework directive

DPSIR

LULC

Systematic transitions

Mondego river basin

Portugal

\section{G R A P H I C A L A B S T R A C T}

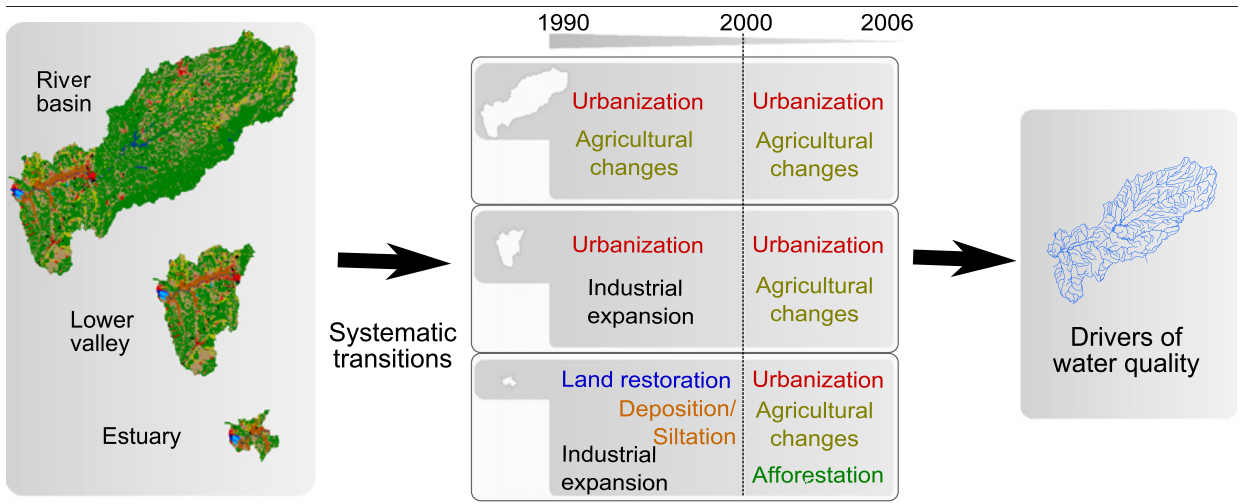

\begin{abstract}
A B S T R A C T
Land use and land cover (LULC) are driving forces that potentially exert pressures on water bodies, which are most commonly quantified by simply obtained aggregated data. However, this is insufficient to detect the drivers that arise from the landscape change itself. To achieve this objective one must distinguish between random and systematic transitions and identify the transitions that show strong signals of change, since these will make it possible to identify the transitions that have evolved due to population growth, industrial expansion and/or changes in land management policies. Our goal is to describe a method to characterize driving forces both from LULC and dominant LULC changes, recognizing that the presence of certain LULC classes as well as the processes of transition to other uses are both sources of stress with potential effects on the condition of water bodies. This paper first quantifies the driving forces from LULC and also from processes of LULC change for three nested regions within the Mondego river basin in 1990, 2000 and 2006. It then discusses the implications for the environmental water body condition and management policies. The fingerprint left on the landscape by some of the dominant changes found, such as urbanization and industrial expansion, is, as expected, low due to their proportion in the geographic regions under study, yet their magnitude of change and consistency reveal strong signals of change regarding the pressures acting in the system. Assessing dominant LULC changes is vital for a comprehensive study of driving forces with potential impacts on water condition.

(c) 2013 Elsevier B.V. All rights reserved.
\end{abstract}

\footnotetext{
* Corresponding author. Tel.: + 351239836386; fax: +351239823603. E-mail addresses: zarafani@student.zoo.uc.pt (Z. Teixeira), heliana.teixeira@jrc.ec.europa.eu (H. Teixeira), jcmimar@ci.uc.pt (J.C. Marques).
}

\section{Introduction}

Under the assumption that the relationship between humans and ecosystems relies on a complex, dynamic web of interactions, a change in the human condition might serve to change 
ecosystems both directly and indirectly. An understanding of such interactions can be described in terms of "drivers" of ecosystem change. Drivers, or driving forces, are any natural (e.g. rainfall, temperature) or human-induced factors that cause a change in an ecosystem.

Human-induced driving forces, in particular, are human activities and economic sectors responsible for pressures acting on an ecosystem (Elliott, 2002), whose identification is essential to evaluate the current and the potential impacts of human activity on the status of surface waters (Carey et al., 2011; Lowicki, 2012; Zhou et al., 2012). Moreover, the identification and understanding of those driving forces are essential to the design of interventions that enhance positive and minimize negative impacts on the ecosystem. The water framework directive (WFD) itself presented a guidance document for the pressure and impact analysis adopting the Driver, Pressure, State, Impact, Response (DPSIR) framework, according to which information on drivers is highly necessary in order to identify pressures and their environmental effect (IMPRESS, 2003).

Land use and land cover (LULC) are important drivers of change to biogeochemical cycles, biodiversity and water quality. Li et al. (2011) found that changes in global land vegetation affected the silicon ( $\mathrm{Si}$ ) uptake by land biomass, causing changes in Si river inputs. The impacts of such land use changes on functional guilds of benthic invertebrates were then evaluated through Eco-Exergy ( $\mathrm{Li}$ et al., 2013). Wang et al. (2013) assessed spatial-temporal water quality variations, identifying LULC sources of water pollution. Measuring LULC and its rates and patterns of change requires a spatial-temporal assessment of LULC data, which is most commonly provided through the analysis of transitional matrices (Lu et al., 2004). The traditional analysis of transitional matrices provides information on the most prominent landscape changes, but is insufficient for distinguishing between random and systematic transitions (Pontius et al., 2004). Random transitions are influenced by coincidental or unique processes of change, whereas systematic transitions are those that tend to evolve in a consistent and/or progressive manner due to population growth, industrial or commercial expansion, or changes in land management policies (Braimoh, 2006; Lambin et al., 2003). The identification of systematic transitions makes it possible to focus on the strongest signals of landscape change and ultimately to link pattern to process (Manandhar et al., 2010; Pontius et al., 2004). Pontius et al. (2004) proposed a methodology to assess inter-category transitions based on systematic transitions while accounting for land persistence. Among other applications, such methodology has been applied to explore the impacts of land use on regional water balance and revegetation strategies (Versace et al., 2008); to assess landscape dynamism to be considered in models of LULC change (Lira et al., 2012); to link patterns to processes of LULC changes based on levels of intensity analysis (Huang et al., 2012); and to detect the dynamic linkage between landscape characteristics and water quality evaluating the statistical relationship between landscape metrics and physical-chemical parameters (Huang et al., 2013). It has also been used to provide a set of pressures on biodiversity derived from LULC changes covering a metropolitan area in Chile (Rojas et al., 2013) and for a spatial-temporal land use change analysis in a peri-urban area within the same river basin used as a case study in this paper (Tavares et al., 2012). Yet, as far as we know, it has never been used as a tool to explicitly identify and quantify drivers of environmental change linked both to LULC and LULC change with potential effects on the condition of water bodies.

Driving forces linked to LULC are regularly quantified by the surface occupied by a specified class (IMPRESS, 2003). However, this method might be insufficient since a LULC class with a small area might leave a larger than expected fingerprint on the landscape if we also consider its rate of transition. Moreover, this method provides information on the drivers linked to the sole presence of the specified LULC, but is unable to provide information on the drivers linked to the process of land transition. Our major goal is therefore to characterize driving forces linked both to LULC and LULC change, with potential impacts on the condition of water bodies. Ultimately, our study intends to contribute to the assessment of land use and land use change in the scope of the WFD, providing instruments to improve the analysis of pressures and impacts (IMPRESS, 2003).

In this study, LULC is characterized and quantified by exploring traditional cross-tabulation matrices over a sixteen-year period (1990-2006), in three nested regions in the Mondego river basin, Portugal. From these results, the role of each LULC class as a driving force of environmental change with impact on the state of water bodies is discussed. Our study then follows the methodology proposed by Pontius et al. (2004) and further extended by Braimoh (2006) as a mean to detect systematic transitions and dominant signals of landscape change, providing the basis for the identification of dominant driving forces from processes of LULC change.

\section{Materials and methods}

\subsection{Study site}

The Mondego river basin is located in the central region of Portugal, Europe (Fig. 1). With an area of $6658 \mathrm{~km}^{2}$ and a NE-SW orientation, it encompasses 36 municipalities with an estimated population of 165 inhabitants per $\mathrm{km}^{2}$ (INE, 2011). Coimbra and Figueira da Foz are two of the most populated municipalities and, because they have grown along the river margins, they play an important role within the Mondego river dynamics.

\subsection{Study regions}

A first analysis of the study area indicated that a reduced number of LULC classes together occupy more than $88 \%$ of the total river basin area. To overcome the dominance of these LULC classes, as well as clumpiness, which could mask relevant driving forces acting in the lower part of the Mondego river basin, analysis was performed for three nested regions within the Mondego river basin: the river basin itself, the Mondego lower valley and the Mondego estuary region (Fig. 1). Identical regions have been previously employed for studies under this same system (Pinto et al., 2010). The Mondego lower valley comprises the subwatersheds draining into the Mondego river and its tributaries, downstream from the city of Coimbra. This region is integrated in the Lower Mondego NUTSIII subregion (EUROSTAT). The Mondego estuary region comprises the subwatersheds draining into the Mondego estuary, plus adjacent subwatersheds draining into the Mondego estuary tributaries. Subwatersheds were defined using the watershed delineation plugin (Moya, 2011) available on MapWindow GIS (version 4.8.6) and were based on SRTM 90 m digital elevation data (version 4.1.) derived from USGS/NASA SRTM data (Jarvis et al., 2008). The Mondego river basin limits available from the Portuguese Environment Agency (APA) were used as a focusing mask and a threshold of $25 \mathrm{~km}^{2}$ was used for network delineation. The resulting stream net coincides with the hydrographic network available also from APA, except for floodplains in the lower part of the Mondego river. The current hydrographic network is not consistent with the expected bounded hydrologic systems, because the Mondego river has undergone several regularization works since the sixteenth century, which have modified its lower part (PBH do Rio Mondego, 1998). 


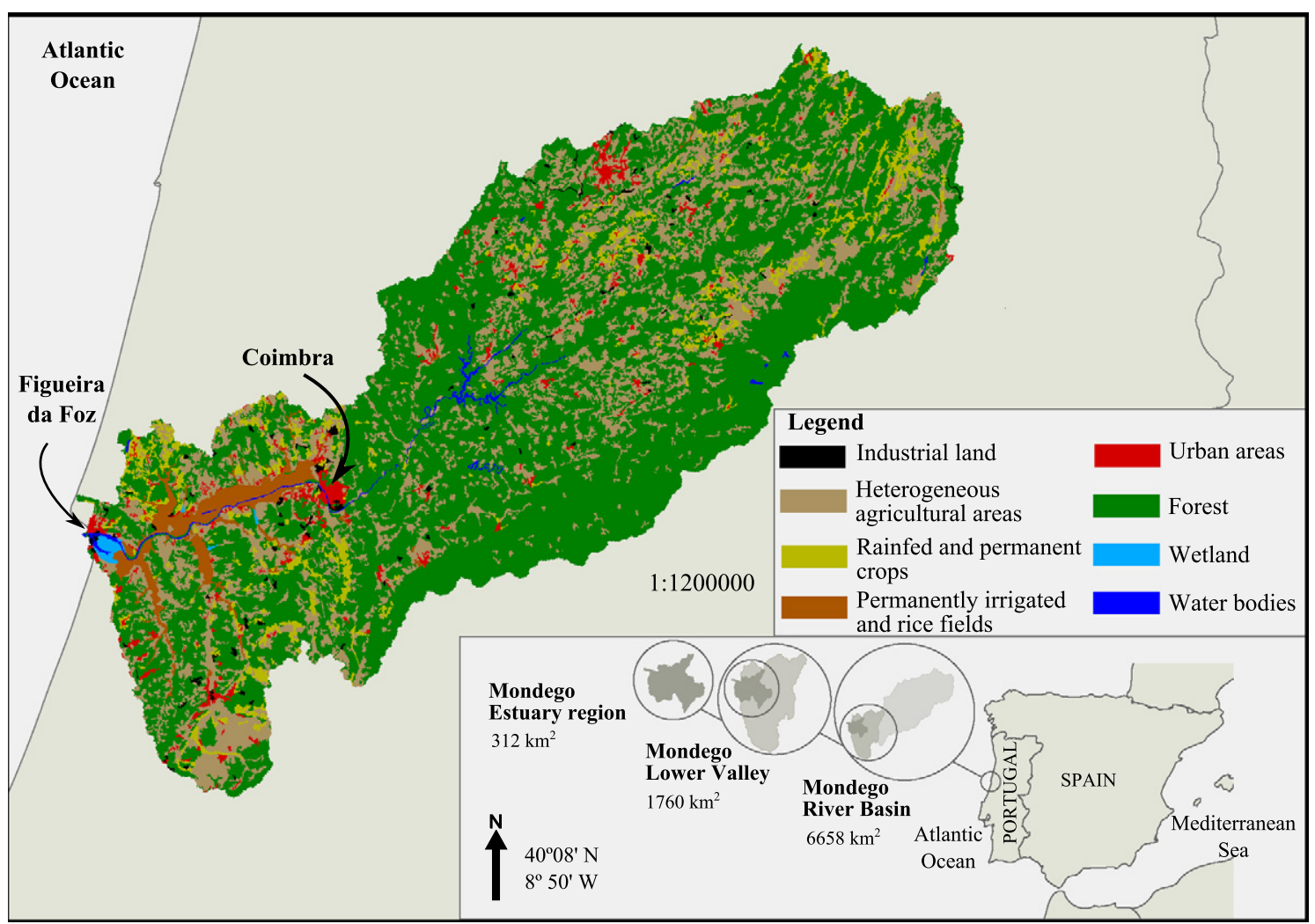

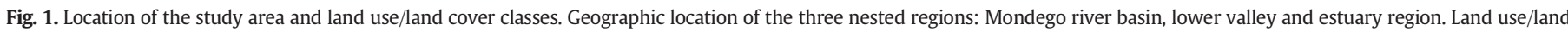
cover reclassification based on the 2006 inventory of the CORINE Land Cover project.

\subsection{LULC reclassification}

To quantify LULC driving forces we defined six LULC classes based on water retention capacity and potential pressures on water bodies, plus two more classes characterizing the water environment (water bodies and wetlands). Of the six LULC classes, two characterize artificial surfaces (urban areas and industrial land), three characterize agricultural areas (rainfed and permanent crops; permanently irrigated land and rice fields; heterogeneous agricultural areas) and the last one characterizes forests (see Table A.1 for a more detailed description of each class). Hereafter these classes are referred to as urban, industrial land, rainfed, rice fields, heterogeneous, forest, wetlands and water bodies.

The analysis was based on CORINE Land Cover raster data, resolution $100 \times 100 \mathrm{~m}$, for the 1990, 2000 and 2006 inventories. CORINE was selected for the analysis because it is a ready-to-use dataset, allowing for replications and comparison to other European sites. The latest versions available, from May 2012, were used (EEA, 2012). The 44 classes of CORINE were reclassified using Quantum GIS 1.8.0 'Lisboa' (OSGeo4W).

\subsection{LULC characterization}

LULC was characterized by calculating the proportion of total landscape occupied by each class in 1990, 2000 and 2006, in the three nested regions. In order to obtain this information, transition matrices were built. Transition matrices are tables displaying classes of time period 1 in rows and classes of time period 2 in columns. The Total column shows the proportion of a class in time period 1, while the Total row shows the proportion of a class in time period 2. Entries on the diagonal of the matrix indicate the proportion of landscape that remained unchanged during the time period analyzed, whereas the remaining cells indicate the proportion of landscape surface of a given LULC class that changed to a different class. This means that off-diagonal entries indicate a transition from a given class in time period 1 to a different class in time period 2 .

For a better characterization of landscape changes, the annual rate of landscape change, the net change and swap were also calculated. The annual rate of landscape change measures the amount of LULC change per year, for each time interval. It was calculated following the approach proposed by Puyravaud (2003) and described in Eq. (1)

$\mathrm{r}=\left(1 / t_{2}-\mathrm{t}_{1}\right) \ln \left(A_{2} / A_{1}\right)$

where $A_{1}$ and $A_{2}$ are the landscape cover of a given LULC class at times $t_{1}$ and $t_{2}$, respectively. The net change measures the definite change between two periods of time (Pontius et al., 2004). It was determined by calculating the difference between the Total column and the Total row. The swapping component of landscape change, i.e., the proportion of a given class that changes location, while the total surface area remains the same, was calculated as the difference between the total change, i.e. gain plus loss, and the absolute value of net change. The relevance of swap lies in the fact that a lack of net change does not necessarily mean a lack of change in the landscape.

In order to assess the total disagreement between maps of two different time periods, quantity disagreement and allocation disagreement were also determined. Total disagreement provides a measure of the total differences between two maps. Quantity disagreement measures the amount of difference in the proportions of the classes. Allocation disagreement measures the amount of difference in the spatial allocation of the classes, given the proportions of the classes (Pontius and Millones, 2011). Such parameters were 
Table 1

Land use/land cover characterization and main landscape changes occurred in the Mondego river basin, lower valley and estuary region, from 1990 to 2006.

\begin{tabular}{|c|c|c|c|c|c|c|c|c|c|c|c|c|c|c|c|c|c|c|c|c|c|c|c|c|c|}
\hline \multirow{2}{*}{ 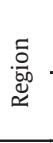 } & \multirow{2}{*}{$\begin{array}{l}\begin{array}{l}\text { LULC } \\
\text { class }^{\text {a }}\end{array} \\
\text { Time } \\
\text { period }\end{array}$} & \multicolumn{3}{|c|}{$\begin{array}{c}\text { Total area } \\
\text { (\% of landscape) }\end{array}$} & \multicolumn{3}{|c|}{$\begin{array}{c}\text { Persistence } \\
\text { (\% of class in time 1) }\end{array}$} & \multicolumn{3}{|c|}{$\begin{array}{c}\mathrm{r}^{\mathrm{b}} \\
(\times 100) \\
\end{array}$} & \multicolumn{3}{|c|}{$\begin{array}{c}\text { Loss } \\
\text { (\% of landscape) }\end{array}$} & \multicolumn{3}{|c|}{$\begin{array}{c}\text { Gain } \\
\text { (\% of landscape) }\end{array}$} & \multicolumn{3}{|c|}{$\begin{array}{c}\text { Total change } \\
\text { (\% of landscape) }\end{array}$} & \multicolumn{3}{|c|}{$\begin{array}{c}\text { Absolute value of net } \\
\text { change }^{c}\end{array}$} & \multicolumn{3}{|c|}{ Swap } \\
\hline & & 1990 & 2000 & 2006 & $\begin{array}{l}1990- \\
2000\end{array}$ & $\begin{array}{l}2000- \\
2006\end{array}$ & $\begin{array}{l}1990- \\
2006\end{array}$ & $\begin{array}{l}1990- \\
2000\end{array}$ & $\begin{array}{l}2000- \\
2006\end{array}$ & $\begin{array}{l}1990- \\
2006\end{array}$ & $\begin{array}{l}1990- \\
2000\end{array}$ & $\begin{array}{l}2000- \\
2006\end{array}$ & $\begin{array}{l}1990- \\
2006\end{array}$ & $\begin{array}{l}1990- \\
2000\end{array}$ & $\begin{array}{l}2000- \\
2006\end{array}$ & $\begin{array}{l}1990- \\
2006\end{array}$ & $\begin{array}{l}1990- \\
2000\end{array}$ & $\begin{array}{l}2000- \\
2006\end{array}$ & $\begin{array}{l}1990- \\
2006\end{array}$ & $\begin{array}{l}1990- \\
2000\end{array}$ & $\begin{array}{l}2000- \\
2006\end{array}$ & $\begin{array}{l}1990- \\
2006\end{array}$ & $\begin{array}{l}1990- \\
2000\end{array}$ & $\begin{array}{l}2000- \\
2006\end{array}$ & $\begin{array}{l}1990- \\
2006\end{array}$ \\
\hline \multirow{9}{*}{ 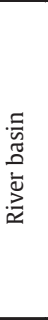 } & $\mathrm{U}$ & 1.16 & 1.48 & 2.34 & 99.83 & 98.05 & 98.00 & 2.46 & 7.63 & 4.40 & 0.00 & 0.03 & 0.02 & 0.32 & 0.89 & 1.20 & 0.33 & 0.91 & 1.23 & 0.32 & 0.86 & 1.18 & 0.00 & 0.06 & 0.05 \\
\hline & I & 0.22 & 0.56 & 0.68 & 94.10 & 87.94 & 82.36 & 9.36 & 3.13 & 7.02 & 0.01 & 0.07 & 0.04 & 0.35 & 0.18 & 0.49 & 0.37 & 0.25 & 0.53 & 0.34 & 0.12 & 0.46 & 0.03 & 0.13 & 0.08 \\
\hline & $\mathrm{R}$ & 5.62 & 5.94 & 5.48 & 98.86 & 89.14 & 88.86 & 0.57 & -1.36 & -0.16 & 0.06 & 0.65 & 0.63 & 0.39 & 0.18 & 0.49 & 0.45 & 0.82 & 1.11 & 0.33 & 0.47 & 0.14 & 0.13 & 1.29 & 1.25 \\
\hline & $\mathrm{P}$ & 2.53 & 2.54 & 2.53 & 99.58 & 97.86 & 97.42 & 0.04 & -0.06 & 0.00 & 0.01 & 0.05 & 0.07 & 0.02 & 0.05 & 0.07 & 0.03 & 0.10 & 0.13 & 0.01 & 0.01 & 0.00 & 0.02 & 0.11 & 0.13 \\
\hline & $\mathrm{H}$ & 25.26 & 24.72 & 24.01 & 97.37 & 94.57 & 92.18 & -0.21 & -0.49 & -0.32 & 0.66 & 1.34 & 1.98 & 0.13 & 0.63 & 0.73 & 0.79 & 1.97 & 2.70 & 0.53 & 0.71 & 1.25 & 1.33 & 2.69 & 3.95 \\
\hline & $\mathrm{F}$ & 64.53 & 63.99 & 64.19 & 99.10 & 99.12 & 98.27 & -0.08 & 0.05 & -0.03 & 0.58 & 0.56 & 1.11 & 0.05 & 0.76 & 0.78 & 0.63 & 1.32 & 1.89 & 0.53 & 0.20 & 0.33 & 1.17 & 1.12 & 2.23 \\
\hline & W & 0.19 & 0.19 & 0.19 & 97.73 & 100.00 & 97.73 & 0.46 & 0 & 0.29 & 0.00 & 0 & 0.00 & 0.01 & 0 & 0.01 & 0.02 & 0 & 0.02 & 0.01 & 0 & 0.01 & 0.01 & 0 & 0.01 \\
\hline & WB & 0.52 & 0.57 & 0.59 & 98.98 & 99.66 & 98.63 & 1.05 & 0.50 & 0.85 & 0.01 & 0.00 & 0.01 & 0.06 & 0.02 & 0.08 & 0.07 & 0.02 & 0.09 & 0.06 & 0.02 & 0.07 & 0.01 & 0.00 & 0.01 \\
\hline & Total & 100 & 100 & 100 & 98.65 & 97.30 & 96.15 & & & & 1.35 & 2.70 & 3.85 & 1.35 & 2.70 & 3.85 & 1.35 & 2.70 & 3.85 & 1.07 & 1.19 & 1.72 & 1.35 & 2.70 & 3.85 \\
\hline \multirow{9}{*}{ 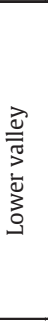 } & U & 2.43 & 279 & 4.58 & 99.69 & 98.03 & 97.76 & 1.40 & 8.25 & 3.97 & 0.01 & 0.06 & 0.05 & 0.37 & 1.84 & 2.21 & 0.38 & 1.90 & 2.26 & 0.36 & 1.79 & 2.15 & 0.01 & 0.11 & 0.11 \\
\hline & I & 0.59 & 1. & 1.47 & 96.03 & 89.12 & 89.07 & 7.82 & 2.09 & 5.67 & 0.02 & 0.14 & 0.06 & 0.73 & 0.31 & .94 & 75 & 6 & 1.01 & 0.70 & 0.17 & 0.88 & 0.05 & .28 & 0.13 \\
\hline & $\mathrm{R}$ & 9.38 & 9.26 & 8.65 & 97.90 & 90.63 & 88.73 & -0.13 & -1.12 & -0.50 & 0.20 & 0.87 & 1.06 & 0.08 & 0.26 & 0.33 & 0.27 & 1.13 & 1.39 & 0.12 & 0.60 & 0.72 & 0.15 & 1.53 & 0.67 \\
\hline & $P$ & 9.31 & 9.35 & 9.31 & 99.56 & 97.83 & 97.39 & 0.04 & -0.07 & 0 & 0.04 & 0.20 & 0.24 & 0.08 & 0.16 & 0.24 & 0.12 & 0.37 & 0.49 & 0.04 & 0.04 & 0.00 & 0.08 & 0.33 & 0.49 \\
\hline & $\mathrm{H}$ & 29.29 & 28.92 & 27.23 & 98.37 & 91.66 & 90.21 & -0.13 & -1.00 & -0.45 & 0.48 & 2.41 & 2.87 & 0.11 & 0.73 & 0.81 & 0.58 & 3.14 & 3.68 & 0.37 & 1.69 & 2.06 & 0.21 & 45 & 1.63 \\
\hline & $\mathrm{F}$ & 47.56 & 46.94 & 47.28 & 98.48 & 99.12 & 97.65 & -0.13 & 0.12 & -0.04 & 0.72 & 0.41 & 1.12 & 0.09 & 0.76 & 0.83 & 0.82 & 1.17 & 1.95 & 0.63 & 0.34 & 0.29 & 0.19 & .83 & 1.67 \\
\hline & W & 0.71 & 0.74 & 0.74 & 97.73 & 100.00 & 97.73 & 0.46 & 0 & 0.29 & 0.02 & 0 & 0.02 & 0.05 & 0 & 0.05 & 0.07 & 0 & 0.07 & 0.03 & 0 & 0.03 & 0.03 & 0 & 0.03 \\
\hline & WB & 0.73 & 0.71 & 0.73 & 97.24 & 99.76 & 97.00 & -0.28 & 0.51 & 0.01 & 0.02 & 0 & 0.02 & 0 & 0.02 & 0.02 & 0.02 & 0.03 & 0.05 & 0.02 & 0.02 & 0.00 & 0 & 0.00 & 0.04 \\
\hline & Total & 100 & 100 & 100 & 98.49 & 95.91 & 94.55 & & & & 1.51 & 4.09 & 5.45 & 1.51 & 4.09 & 5.45 & 1.51 & 4.09 & 5.45 & 1.14 & 2.33 & 3.07 & .37 & 1.77 & 2.38 \\
\hline \multirow{9}{*}{$\begin{array}{l}\text { 怘 } \\
\text { 总 }\end{array}$} & U & 3.67 & 4.00 & 4.60 & 100 & 96.76 & 96.56 & 0.85 & 2.34 & 0.85 & 0 & 0.13 & 0.13 & 0.33 & 0.73 & 1.06 & 0.33 & 0.86 & 1.18 & 0.33 & 0.60 & 0.33 & 0 & 0.26 & 0 \\
\hline & I & 0.91 & 1.47 & 1.25 & 100 & 74.01 & 79.43 & 4.76 & -2.75 & 4.76 & 0 & 0.38 & 0.19 & 0.56 & 0.16 & 0.52 & 0.56 & 0.54 & 0.71 & 0.56 & 0.22 & 0.56 & 0 & 0.32 & 0 \\
\hline & $\mathrm{R}$ & 7.38 & 7.32 & 6.22 & 99.17 & 82.53 & 81.84 & -0.08 & -2.70 & -0.08 & 0.06 & 1.28 & 1.34 & 0 & 0.18 & 0.18 & 0.06 & 1.46 & 1.52 & 0.06 & 1.09 & 0.06 & 0 & 0.37 & 0 \\
\hline & $\mathrm{P}$ & 21.40 & 21.56 & 21.61 & 99.23 & 99.94 & 99.17 & 0.07 & 0.04 & 0.07 & 0.17 & 0.01 & 0.18 & 0.32 & 0.06 & 0.38 & 0.48 & 0.08 & 0.56 & 0.15 & 0.05 & 0.15 & 0.33 & 0.03 & 0.33 \\
\hline & $\mathrm{H}$ & 3.91 & 23.40 & 23.79 & 97.74 & 96.31 & 94.15 & -0.22 & 0.28 & -0.22 & 0.54 & 0.86 & 1.40 & 0.03 & 1.26 & 1.28 & 0.57 & 2.12 & 2.68 & 0.51 & 0.39 & 0.51 & 0.06 & 1.73 & 0.06 \\
\hline & $\mathrm{F}$ & 36.45 & 35.91 & 36.18 & 97.81 & 98.95 & 96.84 & -0.15 & 0.12 & -0.15 & 0.80 & 0.38 & 1.15 & 0.26 & 0.65 & 0.88 & 1.06 & 1.03 & 2.04 & 0.54 & 0.27 & 0.54 & 0.52 & 0.76 & 0.52 \\
\hline & W & 3.63 & 3.82 & 3.82 & 97.50 & 100.00 & 97.50 & 0.50 & 0 & 0.50 & 0.09 & 0 & 0.09 & 0.28 & 0 & 0.28 & 0.37 & 0 & 0.37 & 0.19 & 0 & 0.19 & 0.18 & 0 & 0.18 \\
\hline & WB & 2.64 & 2.53 & 2.53 & 95.72 & 99.87 & 95.59 & -0.44 & 0 & -0.44 & 0.11 & 0.00 & 0.12 & 0 & 0.00 & 0.00 & 0.11 & 0.01 & 0.12 & 0.11 & 0 & 0.11 & 0 & 0.01 & 0 \\
\hline & Total & 100 & 100 & 100 & 98.23 & 96.95 & 95.41 & & & & 1.77 & 3.05 & 4.59 & 1.77 & 3.05 & 4.59 & 1.77 & 3.05 & 4.59 & 1.22 & 1.32 & 1.22 & 0.55 & 1.73 & 0.55 \\
\hline
\end{tabular}

${ }^{\mathrm{a}} \mathrm{U}$ - urban areas; I - industrial land; $\mathrm{R}$ - rainfed and permanent crops; $\mathrm{P}$ - permanently irrigated and rice fields; $\mathrm{H}$ - heterogeneous agricultural areas; $\mathrm{F}-$ forest; $\mathrm{W}-$ wetlands; $\mathrm{WB}-$ water bodies.

Values in light gray boxes depict net gains (positive net change); values in white boxes depict net losses (negative net change); values in dark gray boxes depict no net change. 


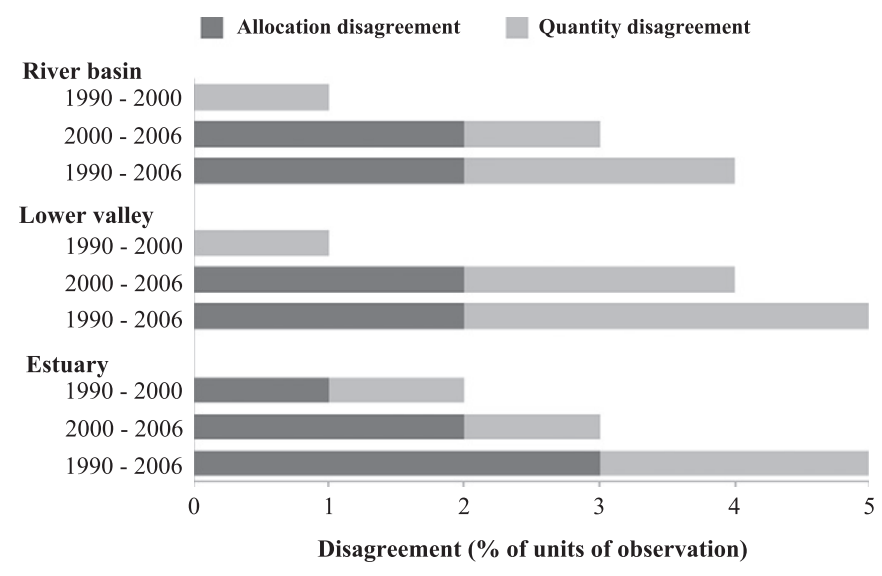

Fig. 2. Total disagreement between LULC maps. Total disagreement expressed by allocation disagreement and quantity disagreement measured for three periods of time and three nested regions in the Mondego river basin.

calculated in terms of number of cells, which represent our units of observation.

\subsection{Systematic transitions}

LULC systematic transitions were identified by examining offdiagonal entries given any level of landscape's degree of persistence and taking into consideration the size of each LULC class. It was assumed that the gain of a given class (difference between the column totals and the unchanged landscape) and its proportion at time 2 was fixed. Likewise, it was assumed that the loss of the same class (difference between row totals and unchanged landscape) and its proportion at time 1 was also fixed. These assumptions, together with the assumption that expected and observed unchanged areas are equal, allowed us to calculate expected values under random processes of gain and loss. The difference between the observed and the expected values provides information on the rate that a given class is to gain - or lose - randomly. This difference is zero if gains - or losses - occurred randomly, and it is not near zero if gains - or losses - are systematic transitions. The magnitude of this difference quantifies the systematic patterns of change and "indicates the size of the fingerprint left on the landscape due to a systematic transition" (Pontius et al., 2004). To simplify the interpretation of the results, only differences higher than $1 \%$ were considered relevant and further discussed. Furthermore, the ratio between this difference and the expected value provides information on the rate that a class gains - or loses - compared to the rate that would be expected if the same class was to gain - or lose - randomly. In this case, the magnitude of the ratio "indicates the strength of the systematic transition". Notice that the factors that promote gains in LULC are most likely different from those that lead to losses and, for this reason, results from the analysis of gains can be different from the analysis of losses. (For further information on systematic transition methodology, please see Pontius et al., 2004.)

\subsection{Dominant processes of LULC change}

Although systematic transitions identify non-random landscape changes, a specific systematic transition might still not be of special importance. Relevance of a systematic transition between two explicit LULC classes is only acknowledged when, for instance, one or several patches of a class of 2006 consistently gain surface from patches of a class of 2000; while in the same time period, one or several patches of the class of 2000 consistently lose surface to patches of that same class of 2006 (Braimoh, 2006).

Once these dominant signals of change were identified, they were compared to 10 potential processes of LULC change (Table A.2) which allowed us to identify the dominant processes of LULC change. Processes of LULC change are broad categories of landscape change and not the actual causes of land modifications, as considered in previous studies (Huang et al., 2012; Manandhar et al., 2010). The approach followed in this study is more appropriate for the identification of driving forces linked to LULC change.

The potential processes of LULC change were defined based on the reclassification of our 8 classes and mainly taking into consideration their potential effect on runoff. Due to the increase of impervious areas and reduction of evapotranspiration and water infiltration, runoff intensification is of special concern because it may cause changes in water flow and chemistry, increase sedimentation, and cause other impacts on biological communities (EPA, 2005; Zhang et al., 2007). The effect on runoff and other potential pressures can be deduced from the description of each LULC available on Table A.1. The potential processes of LULC change are urbanization, industrial expansion, afforestation, agricultural shift, other agricultural changes, agriculturalization, deforestation, land restoration, siltation/deposition and dredging/erosion (see Table A.2 for potential processes of LULC change according to the type of transition). Urbanization refers to the expansion of urban settlement at the expense of other LULC types. Industrial expansion refers to the increase of industrial settlement at the expense of other LULC types. Afforestation refers to conversion from any other LULC type to forest cover. Agricultural shift refers to conversions between rainfed class and rice fields class. Other agricultural changes refer to conversions between one of these two classes and heterogeneous. Agriculturalization refers to the expansion of agricultural areas at the expense of non-agricultural LULC types, except forest. Deforestation refers to the expansion of agricultural areas at the expense of forest. The expansion of agricultural areas from artificial surfaces (agriculturalization) and forest (deforestation) was distinguished because the impact on the hydrologic cycle is potentially different. Land restoration refers to the expansion of wetlands or water bodies at the expense of other LULC types. Siltation/deposition refers to the expansion of wetlands at the expense of water bodies and dredging/erosion refers to the loss of wetlands with subsequent increase in water body surface.

\section{Results}

\subsection{LULC characterization}

The proportion of total landscape occupied by each class characterizes and quantifies LULC in the Mondego river basin, Mondego lower valley and Mondego estuary region, in 1990, 2000 and 2006 (Table 1). All LULC classes show differences in the proportion occupied in each regional scale no matter the year considered. The largest class in all three regions is forest, the surface of which decreases from around $64 \%$ in the river basin, to $47 \%$ in the lower valley and $36 \%$ in the estuary region. The second-largest class - heterogeneous - in turn occupies an area between $23 \%$ and $29 \%$, with only slight differences between regions. On the other hand, the proportion occupied by rice fields increases from around $2.5 \%$ in the river basin to approximately $9 \%$ in the lower valley and $21 \%$ in the Mondego estuary. Artificial surfaces, i.e., urban and industrial land, occupy the lowest landscape proportion in all three regions, with exception for the classes characterizing the water environment. These, as expected, occupy larger proportions downstream from the river basin.

Regarding the differences between years, total disagreement is higher in the last six years (2000-2006) than in the first ten years 
Table 2

Most relevant systematic transitions in the Mondego river basin considering the percentage of land change in terms of gains and losses.

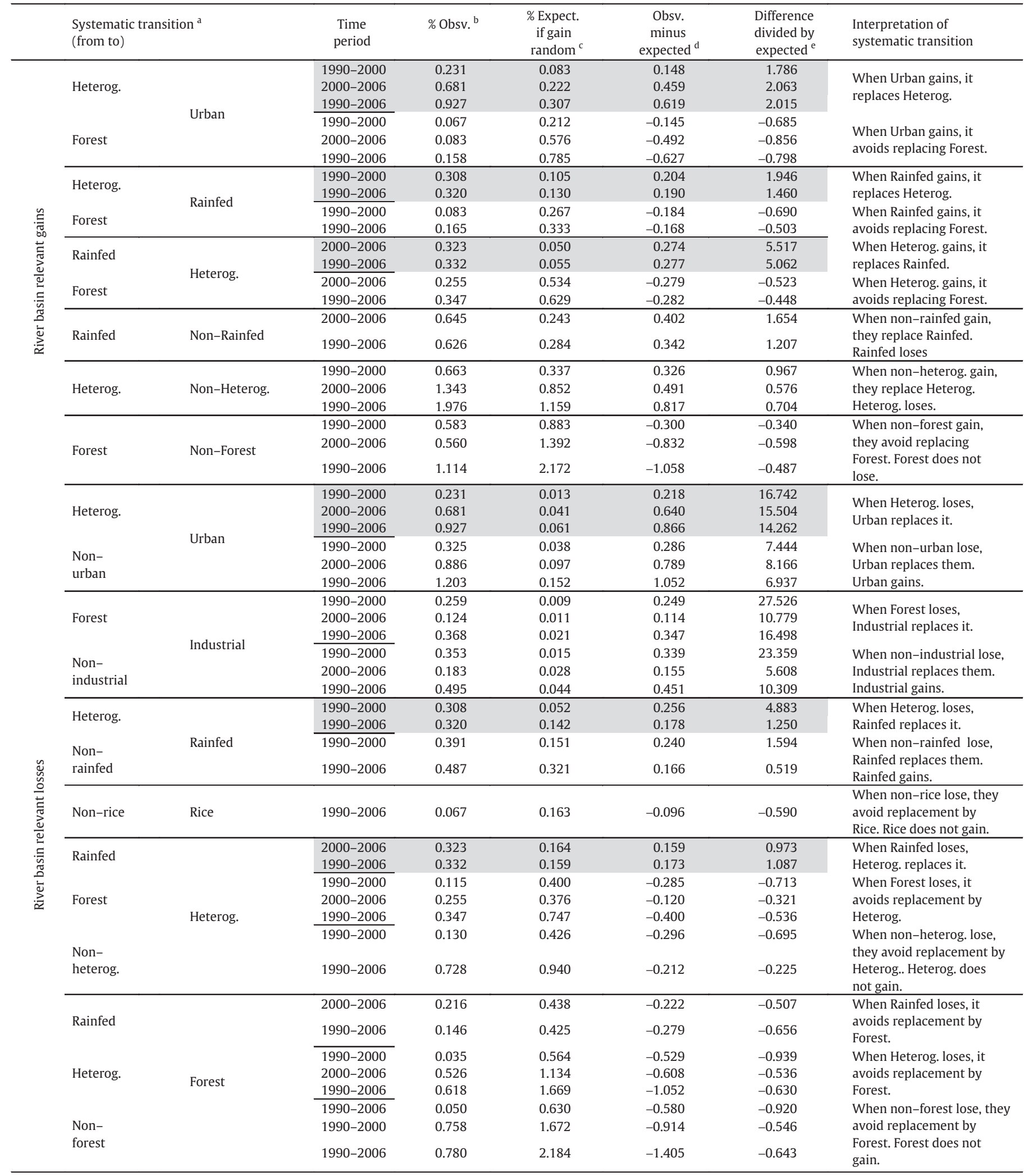

arban - urban areas; Industrial - industrial land; Rainfed - rainfed and permanent crops; Rice - permanently irrigated and rice fields; Heterog. - heterogeneous agricultural areas; Forest - forest.

b\% obsv. - percentage of class observed in time 1.

\% expect. - \% of class expected in time period 2 if gain (or loss) had been random.

${ }^{\mathrm{d}}$ Obsv. minus expected $-\%$ observed minus \% expected.

e Difference divided by expected - \% observed minus \% expected divided by the \% expected.

${ }^{\mathrm{f}}$ Gray boxes identify relevant systematic transitions. 
Table 3

Most relevant systematic transitions in the Mondego lower valley considering the percentage of land change in terms of gains.

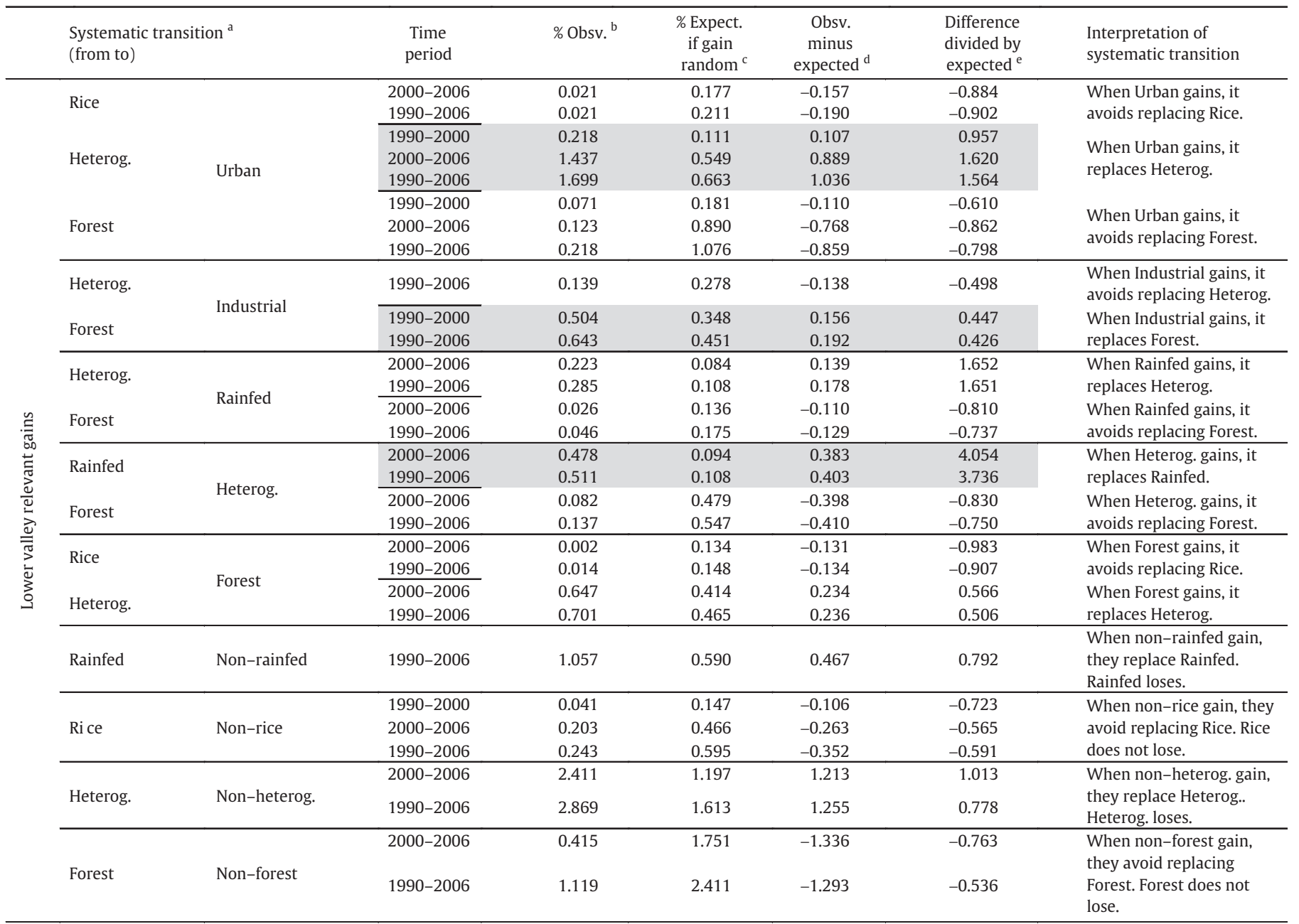

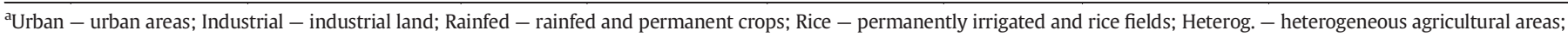

Forest - forest.

b\% obsv. - percentage of class observed in time 1.

c\% expect. $-\%$ of class expected in time period 2 if gain (or loss) had been random.

${ }^{\mathrm{d} O b s v}$. minus expected - \% observed minus \% expected.

e Difference divided by expected - \% observed minus \% expected divided by the \% expected.

${ }^{\mathrm{f}}$ Gray boxes identify relevant systematic transitions.

(1990-2000), in all three regions (Fig. 2). Also, from 1990 until 2000 , only quantity disagreement contributes to total disagreement in the river basin and lower valley, whereas the estuary region shows both quantity and allocation disagreement. Overall, total disagreement does not exceed $5 \%$ of the total units of observation. This is in accordance with the high levels of persistence and low annual rates of land change observed for all classes, in all periods of time, in all regions (Table 1 ). There are some exceptions, though, which are related to artificial surfaces. These show positive and high annual rates of land change during the sixteen-year period. Changes in industrial land took place mostly during the first ten years, while changes in urban took place mostly during the last six years (Table 1).

Despite the low annual rates of change, rainfed, heterogeneous and forest classes show the highest swap, suggesting that these classes, together with artificial surfaces, are the most dynamic LULC classes (Table 1).

\subsection{Systematic transitions}

When a LULC class systematically gains surface from, or loses surface to, another class, the difference between the observed and the expected

Notes to Table 4

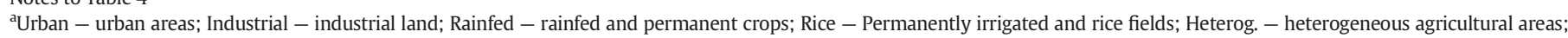
Forest - forest.

b\% obsv. - percentage of class observed in time 1.

c\% expect. - \% of class expected in time period 2 if gain (or loss) had been random.

${ }^{\mathrm{d} O b s v}$. minus expected $-\%$ observed minus \% expected.

e Difference divided by expected - \% observed minus \% expected divided by the \% expected.

${ }^{\mathrm{f}}$ Gray boxes identify relevant systematic transitions. 
Table 4

Most relevant systematic transitions in the Mondego lower valley considering the percentage of land change in terms of losses.

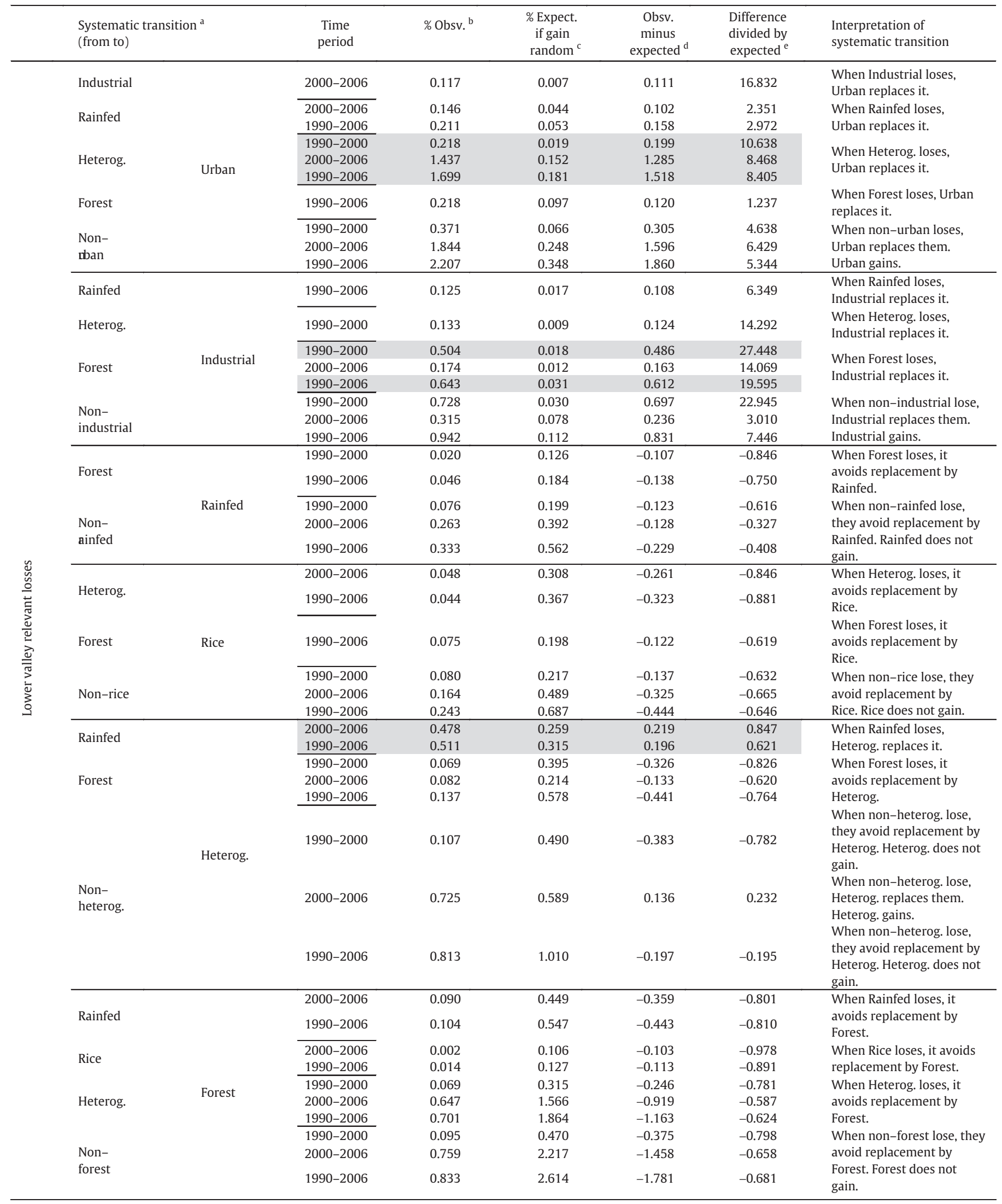


values is different from zero. Results show that the smaller the geographic area under analysis, the higher the number of different systematic transitions found (Tables 2-6). Furthermore, in some cases, for the same geographic area, a transition is only systematic for one time period: for only the first ten years or only the last six, or only when considering the sixteen-year time period.

Systematic transitions observed from other classes to urban are consistent with its positive net change, low swap and high annual rates of change (Table 1). Comparing the observed with the expected transitions based on a random process of loss, heterogeneous, industrial land, rainfed, and forest, they all attracted, at least in the lower valley and estuary regions, a systematic replacement by urban. At the same time, and based on a random process of gain, urban gained surface by systematically replacing heterogeneous (all three regions), rice fields (lower valley and estuary) and industrial land (estuary). Moreover, from 2000 to 2006, the rate of transition from industrial land was over 24 times the rates expected if urban were to gain randomly (Table 5).

Regarding industrial land and from the perspective of gains, this class systematically replaces forest, but when focusing only on the lower valley and the estuary regions. At the same time, industrial land avoids replacing heterogeneous in the lower valley and rice fields in the estuary regions (Tables 3 and 5). From the perspective of losses, however, forest tends to be replaced by industrial land in all three regions, by rates from over 13 times the expected ones in the Mondego estuary (Table 6 ) to over 16 times in the river basin, from 1990 to 2006 (Table 2). Such rates are even higher from 1990 to 2000 reaching values over 27 times the expected if forest were to lose randomly (Table 4). Heterogeneous also tend to be replaced by industrial land from 1990 to 2000, with rates higher than the expected if heterogeneous were to lose randomly: between 10 times in the Mondego estuary (Table 6) and 14 times in the lower valley (Table 4). As a result, industrial land shows positive and high net change and annual rates of change, except in the estuary region during the 2000-2006 period, when industrial land loses surface due to replacement by urban at rates over 15 times the expected if industrial land were to lose randomly (Table 6).

With regard to rainfed, this class systematically replaces heterogeneous and avoids replacing forest. Transitions from heterogeneous to rainfed occur at rates from over 1.4 times up to 1.9 times the rates expected if rainfed class were to gain randomly; and rates from over 1.2 times up to 4.8 times the rates expected if heterogeneous were to lose randomly. Systematic transitions to rainfed occur only at the river basin and in the lower valley regions (Tables 2 and 3). Despite the systematic transitions to rainfed, this class shows net loss and negative annual rates in all three regions, except for the river basin from 1990 to 2000. This is explained by the systematic transitions to urban, industrial land and also heterogeneous classes (Table 1 ).

With respect to heterogeneous, they lose total surface from 1990 to 2006 , in all three regions, due to the aforementioned systematic replacements by urban, industrial land and rainfed and also by forest. However, its swapping dynamics indicates that heterogeneous also replace other classes (Table 1). Results show that when heterogeneous gain, they systematically replace rainfed at rates higher than $3 \%$, in all three regions, while they avoid replacing forest. At the same time, rainfed systematically attracted replacement by heterogeneous, but at lower rates.

Rice fields show low annual rates of change and low swap. This is in accordance with the low number of systematic transitions found, which only shows that, in the lower valley and estuary region, heterogeneous, forest and rainfed avoid replacement by rice fields (Tables 4 and 6) and that, in the estuary region, rice fields avoid replacing heterogeneous (Table 5). At the same time, in the estuary region, wetlands systematically replace rice fields, at rates over 19 times the expected rates if rice fields were to lose randomly (Table 6).
The only class that forest replaces in a systematic manner is heterogeneous. Nonetheless the highest rate found was 1.4 times the expected if forest were to gain randomly, which was found in the estuary region. At the same time, forest avoids replacement by rice fields and also rainfed (Table 5). Moreover, and as mentioned before, the only classes that systematically replace forest are urban and industrial land. Overall, forest has low annual rates of change, shows net loss from 1990 to 2000 and net gain from 2000 to 2006, but has high swap (Table 1 ).

Wetlands, whose proportion is highest in the Mondego estuary region show very low annual rates of change and hardly any swapping changes. However, our study was able to detect that, in the estuary region, when wetlands gain surface it is due to systematic replacement of rice fields and also water bodies.

\subsection{Dominant processes of LULC change}

According to Braimoh (2006) there is a dominant signal of change from class A to class B, if class B systematically loses surface to class A, while at the same time class A systematically gains surface from class B. From this perspective, not all systematic transitions found in this study are actually strong signals of change. For some pairs of classes, this assumption was not fulfilled in any time period or region. In other cases, this assumption was only fulfilled for a specific time period. For all dominant signals of change found, they were always detected when considering the sixteen-year time period, but some were only detected during the first ten years, or during the last six (Fig. 3).

Regarding the entire river basin, the first ten years witnessed strong signals of change from heterogeneous to urban and to rainfed; whereas during the last six years a strong signal was again found from heterogeneous to urban but also from rainfed to heterogeneous.

Regarding the lower valley, during the first ten years dominant signals of change were found from heterogeneous to urban and also from forest to industrial land; whereas during the last six years signals of strong change were found again from heterogeneous to urban, but also from rainfed to heterogeneous.

Finally, and focusing only on the estuary region, during the first ten years strong signals of change were observed from forest to industrial land and from rice fields and water bodies to wetland; whereas during the last six years dominant signals of change were found from industrial land to urban, from rainfed to heterogeneous and from heterogeneous to forest. A dominant signal of change was also detected from heterogeneous to urban, but only when considering the sixteen-year time period.

The dominant signals of change allow us to determine the dominant processes of LULC change (Table A.2). Urbanization and other agricultural changes are common to the three nested regions. Yet, if we take into account only the Mondego lower valley and the estuary regions, then industrial expansion also arises as a dominant process of change. But focusing only on the estuary region, apart from the processes mentioned before, afforestation together with land restoration and siltation/deposition also emerge as dominant processes of change.

\section{Discussion}

\subsection{LULC as driving forces and dynamics over the years}

Each LULC class, with exception to those related to the water environment, has the potential to exert different types of pressure affecting the state of water bodies - from pollution to alteration of hydrologic regime, to changes in morphology and other types of pressure, such as the introduction of new diseases in local fauna and flora (Aguilera et al., 2012; FAO, 1996; Fiquepron et al., 2013). Quantifying the proportion 
Table 5

Most relevant systematic transitions in the Mondego estuary region considering the percentage of land change in terms of gains.

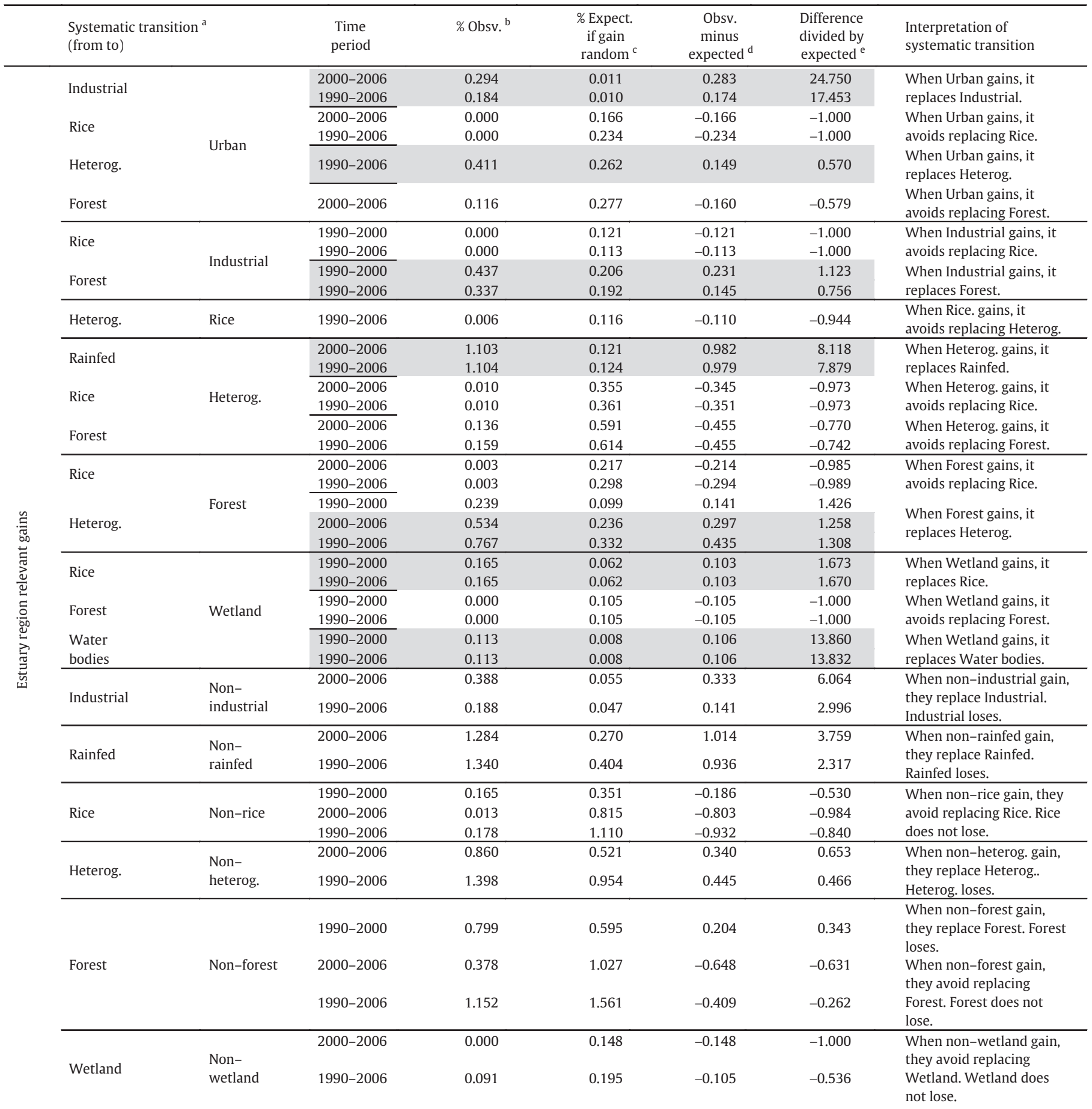

arban - urban areas; Industrial - industrial land; Rainfed - rainfed and permanent crops; Rice - permanently irrigated and rice fields; Heterog. - heterogeneous agricultural areas; Forest - forest.

b\% obsv. - percentage of class observed in time 1.

c\% expect. $-\%$ of class expected in time period 2 if gain (or loss) had been random.

${ }^{\mathrm{d}}$ Obsv. minus expected $-\%$ observed minus \% expected.

${ }^{\mathrm{e}}$ Difference divided by expected - \% observed minus \% expected divided by the \% expected.

${ }^{\mathrm{f}}$ Gray boxes identify relevant systematic transitions.

of each class and its dynamics over the years allows for a first glance over the type and intensity of driving forces acting in an aquatic system.

The driving forces from LULC, i.e., LULC classes with potential impact on aquatic systems, were quantified for three nested regions of the
Mondego river basin, in Central Portugal. Forest, which occupies the largest surface area in all three regions and is associated with good runoff retention and with low diffuse pollution potential (Neary et al., 2009), loses representativeness in the lower valley and estuary regions. 
At the same time, agricultural areas and artificial surfaces, which might critically affect water systems, occupy larger proportions in downstream regions (Table A.1). This general pattern is observable for all the three years analyzed (1990, 2000 and 2006). This means that the type of driving forces did not change over the years or across the regions. Despite this, because the total surface occupied by each class and its overall spatial allocation have changed, we expect changes in the type or intensity of pressures acting on the system. During the sixteen-year period forest lost surface in all three regions, whereas artificial surfaces gained area and showed positive high annual rates of landscape change. Urban and industrial land classes are not only a proxy for impervious areas, but are also a proxy for household and for industrial/commercial estates. As a consequence of both forest decrease and artificial surface increase, there is a potential for runoff increase, promoting the intensification of non-point source pollution from urban drainage, commercial forestry and agriculture (Vidal-Dorsch et al., 2012). At the same time, point-source pollution from wastewater, waste management, industry and contaminated land has also potentially increased. As a result, pesticides, pharmaceuticals (Leston et al., 2011; Santos et al., 2010), endocrine disruptors (Baptista et al., 2013; Nunes et al., 2011; Ribeiro et al., 2009), metals (Couto et al., 2013), organic material, salt, ammonia and other urban contaminants might have increased in the system, though treatment plants can be successful in removing some of them (EPA, 2010). Such alterations in the type and pattern of LULC driving forces could have implications not only on future management policies, but also on monitoring plans and on the selection of biological indicators. Consider, as an example, the increase in industrial areas and the consequent emergence and/ or intensification of sources of pollution, such as pharmaceuticals used in the food production industry to ensure animal welfare. Though several pharmacological substances are already within the scope of researchers, new monitoring programs and biological indicators are needed to assess the wide variety of substances used in the food production industry. Leston et al. (2011, 2013), for instance, advocate that Ulva lactuca should be included as an indicator for nitrofuran and chloramphenicol, two illegal antibiotics still in use in Europe.

With respect to agricultural classes, a decrease in the total surface occupied by rainfed and permanent crops indicates a decline on the pressures derived from the application of fertilizers and other agrochemicals, especially during the irrigation seasons. In contrast, an increase in nutrients could be expected due to the increase of surface occupied by rice fields in the Mondego estuary region. In fact, the Mondego estuary has been under environmental stress by eutrophication processes, in part due to nutrient inputs from surrounding rice fields (Marques et al., 2003). However, mitigation measures implemented in 1998 caused an effective reduction in the N:P atomic ratio leading to a decrease in green macroalgae biomass and an increase in seagrass biomass and cover (Leston et al., 2008; Lillebø et al., 2005). Nonetheless, to return the system to its original state of seagrass dominance, further mitigation measures need to be taken (Marques et al., 2003) and, concordantly, the current Hydrographic Region Management Plan for the Mondego river basin proposes the reduction of nutrient loads into the estuary as one of the main actions to implement in order to achieve good status in all water bodies (ARH do Centro, 2012).

Though our paper quantifies swap between classes, it does not assess landscape patterns and therefore we are unable to discuss the impacts of different configurations in the Mondego river basin. However, it is widely recognized that LULC configuration poses challenges to aquatic systems (Alberti, 2005; Wiens, 2002). As an example, Alberti et al. (2007) showed that the configuration of impervious area and forest influences the ecological conditions of streams.

\subsection{Systematic transitions}

Whether or not the LULC changes observed are a result of random or non-random processes of change is of ultimate importance. Such findings help us focus on transitions that have evolved as a result of consistent processes that can be targeted, described and quantified (e.g. population growth, industrial expansion and changes in land management policies)

This study describes the most prevalent systematic transitions of LULC following the methodology proposed by Pontius et al. (2004), which prevents us from focusing mainly on large transitions, usually between the largest classes. In our case study, this would mean focusing only on transitions between heterogeneous and forest, which, in reality occur at rates not much higher than those that would be expected if the transition were to occur randomly (at maximum, around 1.2 times). On the other hand, identifying the systematic transitions allowed us to realize that the transitions with the highest rates, compared to those expected if the transition had been random, are in fact those involving artificial surfaces, which are also the smallest classes, apart from wetlands and water bodies. This means that despite the low fingerprint left on the landscape by these small classes, transitions to urban and industrial land classes might suggest a transition of pressures acting on the system at a rate higher than expected considering their total area.

Our case study focused on three periods of time - 1990-2000, 20002006 and 1990-2006 - for which we sought systematic transitions. One of the first evidences was that we did not find the same systematic transitions for all time periods, meaning that temporal resolution affects results and therefore interpretation. On the one hand, if a transition is considered systematic only for the entire sixteen-year period, it could mean that the processes causing that transition operated throughout the entire period and were not strong enough to be detected when analyzing the two separate time periods. On the other hand, if a transition is systematic only for one of the time periods under study, it could mean that the causes linked to that specific transition are probably related to some management policy prevailing during that period of time.

The goal of this study was not to evaluate the causes of systematic transitions. Nonetheless, identifying the time periods and the geographic regions where transitions had a non-random behavior is a first step towards identifying such causes. From a precautionary point of view, identifying such causes is of utmost importance, since they are critical for the definition of social-ecological policies and management scenarios (Marques et al., 2009).

The methodology followed also compares systematic transitions among three nested regions - the Mondego river basin, Mondego lower valley and Mondego estuary region. This approach allowed us to focus on LULC relevant systematic transitions downstream the river basin, which would have been masked by transitions involving larger and well distributed classes across the basin. Systematic transitions involving rice fields and wetlands are examples of potentially overlooked transitions. Rice fields are an extremely important driver in the Mondego estuary. In fact, management policies implemented to improve the Mondego estuary water quality have long focused on the reduction of nutrient loadings from rice fields (Dolbeth et al., 2007;

Note to Table 6

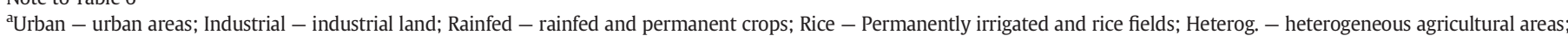
Forest - forest.

b\% obsv. - percentage of class observed in time 1.

c\% expect. - \% of class expected in time period 2 if gain (or loss) had been random.

${ }^{\mathrm{d} O b s v}$. minus expected - \% observed minus \% expected.

e Difference divided by expected - \% observed minus \% expected divided by the \% expected.

${ }^{\mathrm{f}}$ Gray boxes identify relevant systematic transitions. 
Table 6

Most relevant systematic transitions in the Mondego estuary region considering the percentage of land change in terms of losses.

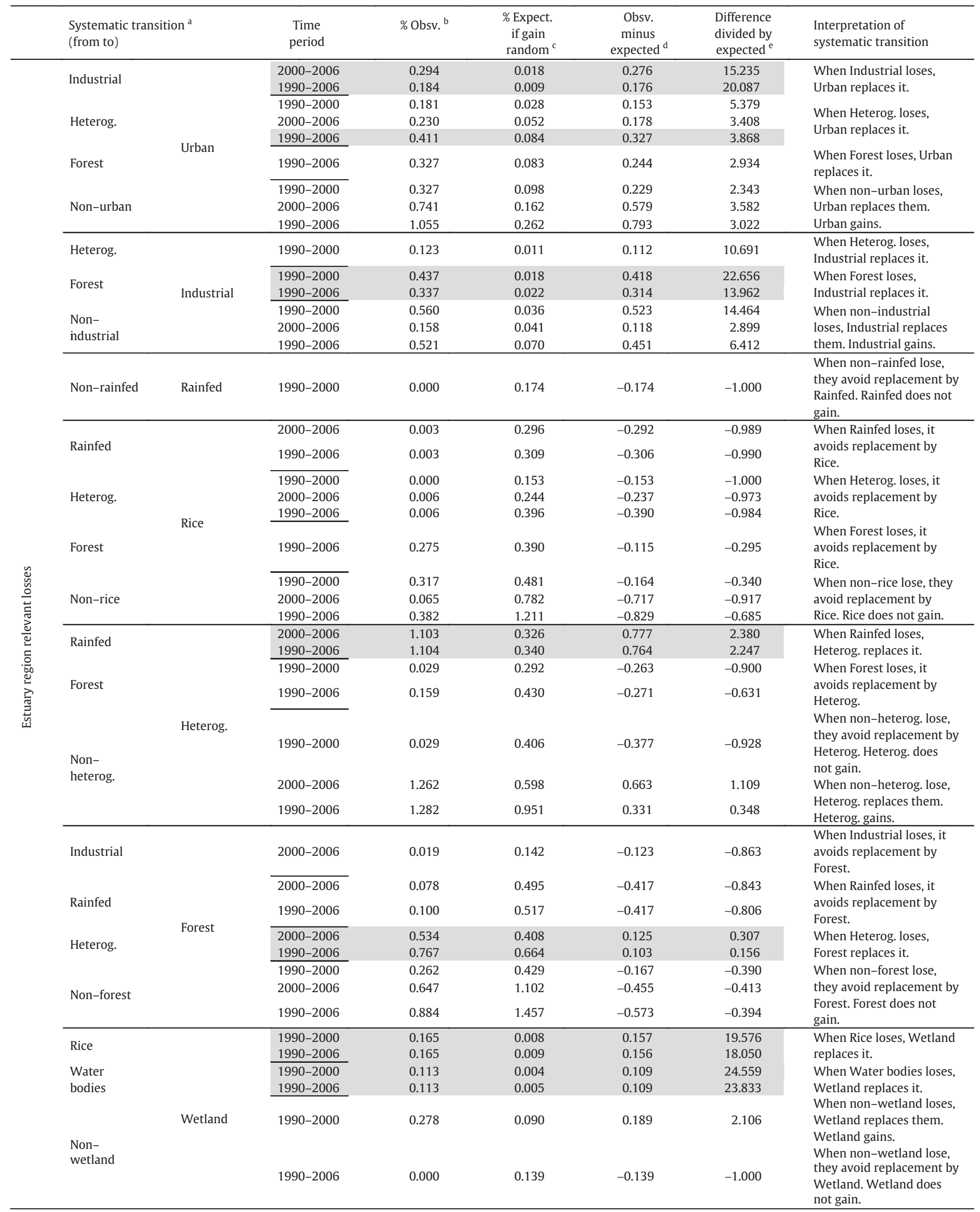


Lillebø et al., 2005). Our analysis with nested regions shows that, in the estuary, despite the overall increase of this class, it was, to some extent, replaced by wetland due to a non-random transition. Similarly, water bodies were also replaced by wetlands in the estuary region, both from the perspective of wetland gains and water body losses. What should be noticed with respect to wetlands is that, no matter what the causes of wetland increase, their presence is important in the Mondego Estuary region for two main reasons: 1) they are representative of wetland values in the west coast of Portugal, being important for birds, while supporting a diverse intertidal macroinvertebrate community (Lopes, 2006); and 2) they can act as natural wastewater treatment plans reducing the nutrient loadings into the estuarine system (Marques et al., 2003).

Previous studies showed that LULC detection analysis should consider different spatial scales, since landscape patterns might change with the resolution of maps (Manandhar et al., 2010). Coarser resolutions tend to show less swap and less inter-class transitions, and yet they can be very useful in finding the distances over which the change occurs (Pontius et al., 2004). Our study was only implemented for $100 \mathrm{~m}$ pixel resolution, though CORINE land cover maps are also provided with $250 \mathrm{~m}$ resolution. Even though CORINE land cover only delivers these two raster products, one with higher resolution, consistent with European standards, is also available from the Portuguese Geographic Institute (IGP, 2010). However, the more detailed levels of this land cover map are not free of cost.

\subsection{Dominant processes of LULC change as driving forces}

Our work assumes that not only the presence of a certain LULC class has an effect on the state of the water bodies, but also that the transition to another use or practice is in itself a source of stress (IMPRESS, 2003). Urbanization and industrial expansion associated with loss of forest and agricultural areas alter hydrology, water chemistry and habitat, which contribute to the degradation of biological communities. Chu et al. (2013), for instance, found that the frequency of average- and highflow events increased with urbanization and decreased with vegetation cover. Wang et al. (2012) found that stream benthic macroinvertebrate metrics are significantly correlated with the percent of impervious area.

Though imperviousness is always foreseeable after the expansion of artificial surfaces, a higher magnitude of response of aquatic systems is expected if artificial areas replace forests than if they replace agricultural areas, since higher hydrologic impacts are expected with the loss of forests (Salazar et al., 2013; Trabucco et al., 2008; Zhang et al., 2001).

Additionally, the magnitude of the impact from an urbanization or industrial expansion process due to loss of agricultural area will depend on the agricultural activities employed previous to transition. Agricultural areas are known to degrade water quality due to impacts such as siltation, turbidity, salinization, erosion, sedimentation and contamination with agrochemicals and toxic leaches, which are a consequence of the agricultural activity employed. For instance, activities with high levels of irrigation promote runoff of salts, fertilizers and pesticides (EPA, 2005). This means that, after an urbanization process, a previously degraded aquatic system might face greater or new environmental problems which might demand new mitigation measures. Likewise, the magnitude of the impact from a change on the agricultural practice due to a change on the type of crop will depend on the practices employed previously. Agricultural transitions between different types of agricultural areas mean a change in water consumption behavior (ARH do Centro, 2012), erosion rates (O'Geen, 2006), type of fertilizers or pesticides, or other sources of pollution (Zhao et al., 2013).

The rates at which a transition occurs should also be at the core of our attention since high transition rates might act in the system as if they were unique and extreme events from which the system will need to recover (Folke, 2006). Transition rates could be used as proxy

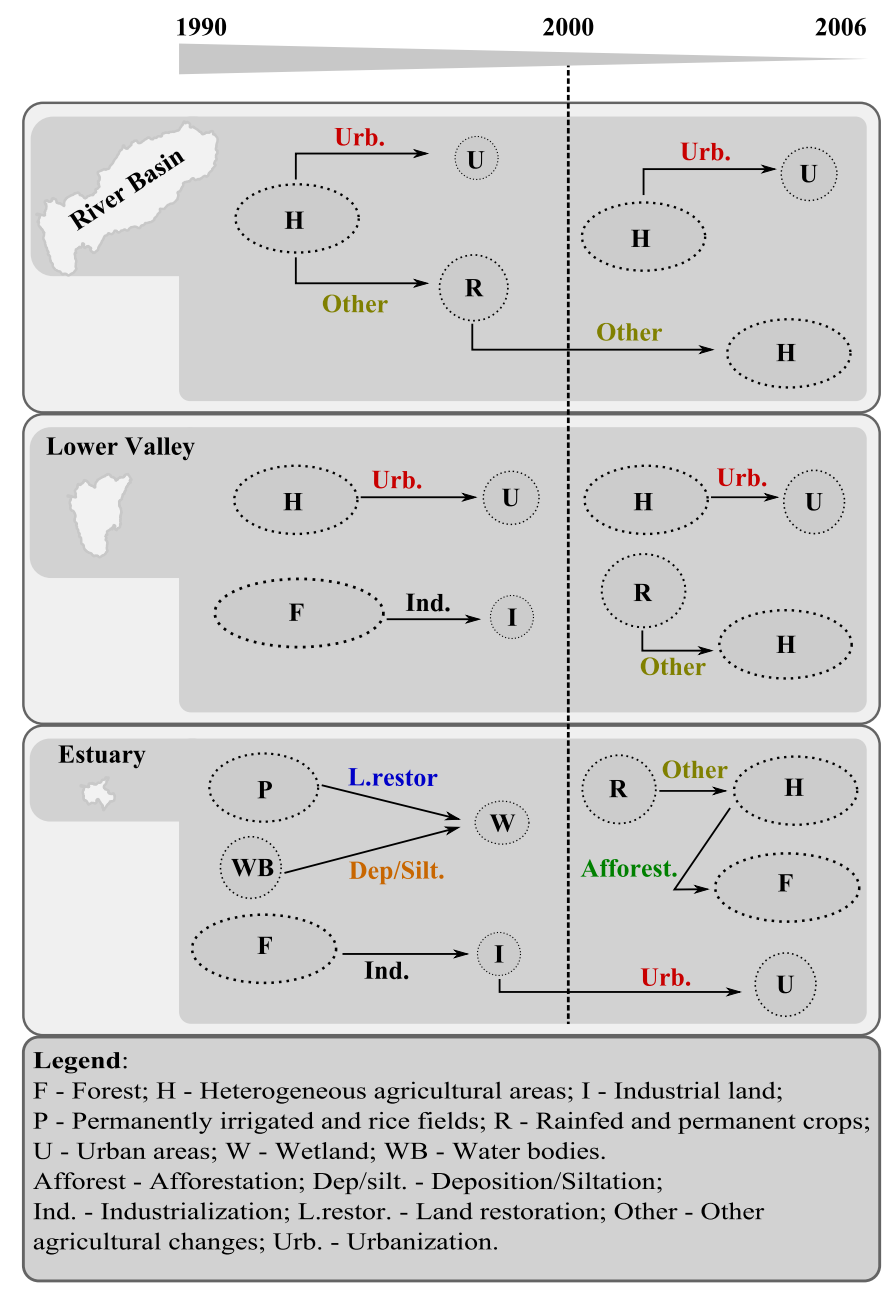

Fig. 3. Dominant processes of LULC change. Systematic transitions revealing strong signals of change found in the Mondego river basin, lower valley and estuary region between 1990 and 2006. The size of each circle approximately represents the proportion occupied by the class at the beginning of the time period, if class loses area, or at the end of the time period if class gains area.

for the pace at which new pressures emerge or the intensity of a certain pressure increases/decreases.

In the Mondego case study, urbanization due to loss of heterogeneous areas and industrial expansion due to loss of forest are two of the most relevant driving forces arising from transitions between LULC classes. Class heterogeneous aggregates associations of annual and permanent crops; areas with juxtaposition of annual and permanent crops; agricultural areas interspersed with natural vegetation and also annual crops under forestry species (EEA, 2012). For its inherent characteristics, heterogeneous classes have uncertain water consumption behavior patterns, and therefore a more detailed analysis would be needed to evaluate the impact of this particular transition. However, impacts typical to any process of urbanization, such as runoff magnification, are still expected. With respect to industrial expansion due to loss of forest, we believe that critical environmental problems might have emerged due to this transition. LULC areas which suffered this transition, changed from an area with good runoff and evapotranspiration characteristics to an impervious area with high potential for contamination.

In addition, the high rates at which the transitions to these artificial classes have occurred suggests that the magnitude of urban and industrial land fingerprints is, and could be in the future, of special concern, specifically with respect to flooding. 
Our study also revealed other agricultural changes as dominant processes of LULC change, mainly due to transitions between heterogeneous and rainfed. In terms of this study, other agricultural changes mean both a heterogenization of agricultural areas as well as the reverse process. In the case of the Mondego river basin, transition rates were higher from rainfed to heterogeneous, than the reverse. This means that the uncertainty with respect to water consumption and water retention behavior as well as agricultural pollution sources has increased at rates higher than those expected if these transitions were to occur randomly.

Notice that rainfed tends to be replaced by heterogeneous and that heterogeneous tends to be replaced by urban. This could mean that abandonment of rainfed and permanent crops could ultimately promote urbanization. However, to clearly assess this relationship further research must be performed.

Focusing only on the estuary region, afforestation at the expense of heterogeneous areas, siltation/deposition and land restoration also stands as dominant processes of LULC change. If afforestation is to fulfill commercial forestry needs, then we can expect an increase or at least an exchange of pesticides or fertilizers in this region and also an increase in pollution sources from planting/ground preparation. Nevertheless, it will always represent an increase in the evapotranspiration and infiltration levels, and therefore a change in the hydrologic and subsequent impacts. Further research focusing on forests, and, particularly, on the geographical area downstream from the city of Coimbra, distinguishing between commercial and non-commercial forestry should be performed. With respect to the process of land restoration, the fact that it is due to the systematic replacement of rice fields by wetlands indicates that a potential change on the pressures associated with intensive agriculture with high consumption of water and high levels of diffuse pollution might have occurred. Moreover, this specific transition is an indication that the expansion of artificial surfaces has not been sustained by land reclamation. Whether or not wetland restoration is a cause or a consequence of rice field disappearance would also need further exploration. With respect to siltation/deposition results show that an existing salt marsh patch increases very close to where the two arms of the estuary communicate. Although finding causes for transitions is not a subject for this study, in this case it is clear that such an increase is consistent with regularization works on the Mondego estuary, during the 90s, when the margins were grounded (Cunha et al., 1997).

\section{Conclusion}

The main objective of this study was to characterize the driving forces linked both to LULC and LULC change, with potential impacts on the condition of water bodies. Driving forces linked to the sole presence of LULC were obtained by quantifying the proportion occupied by each LULC class in three nested regions in the Mondego river basin, in Central Portugal, which was based on the three available CORINE Land Cover projects 1990, 2000 and 2006. Results showed that agricultural areas and artificial surfaces, which are the driving forces that pose the most challenges to aquatic systems, are also the ones whose representativeness increases in downstream regions. Though this evidence might be useful to quantify the importance of each driving force in each region and in each year analyzed, it does not give information on the drivers linked to the processes of land transition. To obtain this information we identified the most relevant driving forces from dominant processes of LULC change through identification and quantification of systematic transitions. The magnitude of change and consistency of transitions revealed that the most relevant driving forces from LULC changes are not necessarily transitions between large classes. We also considered that these transitions revealed changes regarding the pressures acting in the system that might have been overlooked. Systematic transitions indicate that special attention should be paid to magnification of runoff, due both to loss of forests and increase of impervious areas and also to contamination of water bodies either due to new contaminants emerging from urbanized and industrialized areas, or to changes in agricultural practices.
Our work characterized driving forces assessing differences in quantity, but a thorough analysis should also be performed to analyze changes in the configuration, since LULC patterns also play a key role on the type and intensity of pressures acting in the system. Additionally, future work should focus on the underlying processes that caused the observed dominant changes (Huang et al., 2012), since this is also crucial information for the development of effective management strategies.

\section{Conflict of interest statement}

I declare no conflict of interest, including any financial, personal or other relationships with other people or organizations.

\section{Acknowledgments}

The present study was carried using means provided by the research projects RECONNECT (PTDC/MAR/64627/2006), WISER (FP7-ENV-2008-226273), and 3M-RECITAL (LTER/BIA-BEC/0019/ 2009). Additionally, it benefited from two grants attributed by the FCT (Portuguese National Science Foundation): SFRH/BD/74804/ 2010 and SFRH/BPD/82127/2011.

\section{Appendix A}

Table A.1

Land use and land cover classes, their description and correspondence to CORINE Land Cover classes.

\begin{tabular}{|c|c|c|}
\hline LULC class & Description & $\begin{array}{l}\text { CORINE classes } \\
\text { included (CORINE } \\
\text { code) }\end{array}$ \\
\hline Urban areas (U) & $\begin{array}{l}\text { Impermeable and pollution-generating } \\
\text { areas, mainly domestic waste water, } \\
\text { contaminated land from rural sites and } \\
\text { urban drainage }\end{array}$ & $\begin{array}{l}\text { Urban fabric (11) } \\
\text { Artificial, non- } \\
\text { agricultural vegetat- } \\
\text { ed areas (14) }\end{array}$ \\
\hline Industrial land (I) & $\begin{array}{l}\text { Impermeable and pollution-generating } \\
\text { areas, mainly industrial waste water, } \\
\text { discharges and industrial contaminated } \\
\text { land, as well as drainage from industrial } \\
\text { and commercial units }\end{array}$ & $\begin{array}{l}\text { Industrial, } \\
\text { commercial and } \\
\text { transport units (12) } \\
\text { Mine dump and } \\
\text { construction sites } \\
\text { (13) }\end{array}$ \\
\hline $\begin{array}{l}\text { Rainfed and } \\
\text { permanent crops } \\
(\mathrm{R})\end{array}$ & $\begin{array}{l}\text { Extensive and subsistence agricultural } \\
\text { areas, with moderate water } \\
\text { consumption }\end{array}$ & $\begin{array}{l}\text { Non-irrigated arable } \\
\text { land (211) } \\
\text { Permanent crops } \\
\text { (22) }\end{array}$ \\
\hline $\begin{array}{l}\text { Permanently } \\
\text { irrigated land and } \\
\text { rice fields }(\mathrm{P})\end{array}$ & $\begin{array}{l}\text { Intensive agriculture, with high water } \\
\text { consumption. Pollution-generating } \\
\text { areas, mainly diffuse }\end{array}$ & $\begin{array}{l}\text { Permanently } \\
\text { irrigated land (212) } \\
\text { Rice fields (213) }\end{array}$ \\
\hline $\begin{array}{l}\text { Heterogeneous } \\
\text { agricultural areas } \\
(\mathrm{H})\end{array}$ & $\begin{array}{l}\text { Agricultural areas with water } \\
\text { consumption behavior patterns difficult } \\
\text { to classify, due to their heterogeneous } \\
\text { characteristics }\end{array}$ & $\begin{array}{l}\text { Pastures (23) } \\
\text { Heterogeneous } \\
\text { agricultural areas } \\
(24)\end{array}$ \\
\hline Forests (F) & $\begin{array}{l}\text { Areas with good runoff retention, } \\
\text { promoting infiltration, poorly } \\
\text { associated with pollution, although } \\
\text { might be sources of diffuse pollution. } \\
\text { Does not distinguish between } \\
\text { commercial and non-commercial for- } \\
\text { estry. }\end{array}$ & $\begin{array}{l}\text { Forest and semi- } \\
\text { natural areas ( } 3 \text { ) }\end{array}$ \\
\hline Wetlands (W) & $\begin{array}{l}\text { Although ecologically and functionally } \\
\text { parts of the water environment, } \\
\text { wetlands were preserved as a distinct } \\
\text { class because pressures on wetlands } \\
\text { may result in impacts on the ecological } \\
\text { status of water bodies (IMPRESS, 2003). }\end{array}$ & Wetlands (4) \\
\hline Water bodies (WB) & Water environment & Water bodies (5) \\
\hline
\end{tabular}


Table A.2

LULC processes of change according to type of transition from time period 1 to time period 2 .

\begin{tabular}{|c|c|c|c|c|c|c|c|c|c|}
\hline & \multicolumn{9}{|l|}{ Time 2} \\
\hline & LULC Classes & $\mathrm{U}$ & I & $\mathrm{R}^{\mathrm{a}}$ & $\mathrm{P}^{\mathrm{a}}$ & $\mathrm{H}^{\mathrm{a}}$ & $\mathrm{F}$ & W & WB \\
\hline \multirow[t]{8}{*}{ Time 1} & $\mathrm{U}$ & Unchanged & Industrial expansion & Agricult. & Agricult. & Agricult. & Afforestation & Land restoration & Land restoration \\
\hline & I & Urbanization & Unchanged & Agricult. & Agricult. & Agricult. & Afforestation & Land restoration & Land restoration \\
\hline & $\mathrm{R}$ & Urbanization & Industrial expansion & Unchanged & Agricultural shift & $\begin{array}{l}\text { Other agricultural } \\
\text { changes }\end{array}$ & Afforestation & Land restoration & Land restoration \\
\hline & $\mathrm{P}$ & Urbanization & Industrial expansion & Agricultural shift & Unchanged & $\begin{array}{l}\text { Other agricultural } \\
\text { changes }\end{array}$ & Afforestation & Land restoration & Land restoration \\
\hline & $\mathrm{H}$ & Urbanization & Industrial expansion & $\begin{array}{l}\text { Other agricultural } \\
\text { changes }\end{array}$ & $\begin{array}{l}\text { Other agricultural } \\
\text { changes }\end{array}$ & Unchanged & Afforestation & Land restoration & Land restoration \\
\hline & $\mathrm{F}$ & Urbanization & Industrial expansion & Deforestation & Deforestation & Deforestation & Unchanged & Land restoration & Land restoration \\
\hline & W & Urbanization & Industrial expansion & Agricult. & Agricult. & Agricult. & Afforestation & Unchanged & Dredging/erosion \\
\hline & WB & Urbanization & Industrial expansion & Agricult. & Agricult. & Agricult. & Afforestation & Siltation/deposition & Unchanged \\
\hline
\end{tabular}

a Agricult. - agriculturalization.

\section{References}

Aguilera R, Marcé R, Sabater S. Linking in-stream nutrient flux to land use and inter-annual hydrological variability at the watershed scale. Sci Total Environ 2012;440:72-81. http://dx.doi.org/10.1016/j.scitotenv.2012.08.030.

Alberti M. The effects of urban patterns on ecosystem function. Int Reg Sci Rev 2005;28(2):168-92. http://dx.doi.org/10.1177/0160017605275160.

Alberti M, Booth D, Hill K, Coburn B, Avolio C, Coe S, et al. The impact of urban patterns on aquatic ecosystems: an empirical analysis in Puget lowland sub-basins. Landsc Urban Plan 2007;80:345-61. http://dx.doi.org/10.1016/j.landurbplan.2006.08.001.

APA IP. Portuguese Environment Agency. http://intersig-web.inag.pt/intersig. [Accessed 20-03-2013]

ARH do Centro IP. Plano de Gestão das Bacias Hidrográficas dos rios Vouga, Mondego e Lis integradas na Região Hidrográfica 4. Ministério daAgricultura, Mar, Ambiente e Ordenamento do Território; 2012. [http:/www.apambiente.pt/?ref=16\&subref= 7\&sub2ref=9\&sub3ref=834 Acessed 08-01-2013].

Baptista J, Pato P, Tavares S, Duarte AC, Pardal MA. PCB bioaccumulation in three mullet species - a comparison study. Ecotoxicol Environ Saf 2013;94:147-52. http://dx.doi.org/ 10.1016/j.ecoenv.2013.04.011.

Braimoh AK. Random and systematic land-cover transitions in northern Ghana. Agr Ecosyst Environ 2006;113:254-63. http://dx.doi.org/10.1016/j.agee.2005.10. 019.

Carey RO, Migliaccio KW, Li Y, Schaffer B, Kikker GA, Brown MT. Land use disturbance indicators and water quality variability in the Biscayne Bay Watershed, Florida. Ecol Indic 2011;11:1093-104. http://dx.doi.org/10.1016/j.ecolind.2010.12.009.

Chu ML, Knouft JH, Ghulam A, Guzman JA, Pan Z. Impacts of urbanization on river flow frequency: a controlled experimental modeling-based evaluation approach. J Hydrol 2013;495:1-12. http://dx.doi.org/10.1016/j.jhydrol.2013.04.051.

Couto T, Duarte B, Barroso D, Caçador I, Marques JC. Halophytes as sources of metals in estuarine systems with low levels of contamination. Funct Plant Biol 2013. http://dx.doi.org/10.1071/FP12300.

Cunha PP, Dinis JL, Reis RP. Avaliação das modificacõos antrópicas actuais nos sub-ambientes sedimentares do estuário do Mondego. Final Report of Project PEAM/C/GEN/243/93; 1997. p. 152.

Dolbeth M, Cardoso PG, Ferreira SM, Verdelhos T, Raffaelli D, Pardal MA. Anthropogenic and natural disturbance effects on a macrobenthic estuarine community over a 10-year period. Mar Pollut Bull 2007;54:576-85. http://dx.doi.org/10.1016/ j.marpolbul.2006.12.005.

EEA - European Environment Agency. CORINE land cover. http://www.eea.europa.eu/ data-and-maps/, 2012. [Accessed 17-11-2012].

Elliott M. The role of the DPSIR approach and conceptual models in marine environmental management: an example for offshore wind power. EditorialMar Pollut Bull 2002;44(6):iii-vii. http://dx.doi.org/10.1016/S0025-326X(02)00146-7.

EPA - Environmental Protection Agency. Treating contaminants of emerging concern. A literature review database; 2010 [http://water.epa.gov/scitech/swguidance/ ppcp/results.cfm Accessed 11-06-2013].

EPA - Environmental Protection Agency. National management measures to control nonpoint source pollution from urban areas. Publication number EPA 841-B-05-004; 2005. Washington, http://www.stormwaterok.net/EPA\%20Documents/ EPA\%20Natl\%20Mgmt\%20Measures\%20to\%20Control\%20Urban\%20NPS\%2012-05.pdf [Accessed 02-10-2013].

EUROSTAT. Nuts - nomenclature of territorial units for statistics. http://epp.eurostat.ec.europa.eu/portal/page/portal/nuts_nomenclature/introduction. [Acessed 05-03-2013].

FAO - Food and Agriculture Organization of the United Nations. Control of water pollution from agriculture. FAO irrigation and drainage paper 55; 1996. Rome, http:// www.fao.org/docrep/w2598e/w2598e00.htm\#Contents [Acessed 01-10-2013].

Fiquepron J, Garcia S, Stenger A. Land use impact on water quality: valuing forest services in terms of the water supply sector. J Environ Manage 2013;126:113-21. http://dx.doi.org/10.1016/j.jenvman.2013.04.002.

Folke C. Resilience: the emergence of a perspective for social-ecological systems analyses. Glob Environ Chang 2006;16:253-67. http://dx.doi.org/10.1016/j.gloenvcha.2006.04.002.
Huang J, Pontius RG, Li Q Zhang Y. Use of intensity analysis to link patterns with processes of land change from 1986 to 2007 in a coastal watershed of southeast China. Appl Geogr 2012;34:371-84. http://dx.doi.org/10.1016/j.apgeog.2012.01.001.

Huang J, Li Q, Pontius RG, Klemas V, Hong H. Detecting the dynamic linkage between landscape characteristics and water quality in a subtropical coastal watershed, Southeast China. Environ Manage 2013;51:32-44. [http://dx.doi.org/7/s00267-0119793-2].

IGP-Portuguese Geographic Institute. Carta de Ocupação do Solo de Portugal Continental para 2007 (COS2007), Mem Descr; 2010. 79 pp. http://www.igeo.pt/e-IGEO/ egeo_downloads.htm Accessed 12-06-2013.

IMPRESS. Guidance for the analysis of pressures and impacts in accordance with the Water Framework Directive. Common implementation strategy working group 2.1 . Office for Official Publications of the European Communities 92-894-5123-8; 2003 156 pp., https://circabc.europa.eu/faces/jsp/extension/wai/navigation/container.jsp Accessed 12-06-2013.

INE - National Institute of Statistics. Census. http://www.ine.pt, 2011. Acessed 01-02-2013.

Jarvis A, Reuter HI, Nelson A, Guevara E. Hole-filled SRTM for the globe Version 4, available from the CGIAR-CSI SRTM $90 \mathrm{~m}$ Database. http://srtm.csi.cgiar.org/, 2008. [Acessed 28-08-2013].

Lambin EF, Helmut JG, Lepers E. Dynamics of land-use and land-cover change in tropical regions. Annu Rev Environ Resour 2003;28:205-41. http://dx.doi.org/10.1146/ annurev.energy.28.050302.105459.

Leston S, Lillebø AI, Pardal MA. The response of primary producer assemblages to mitigation measures to reduce eutrophication in a temperate estuary. Estuar Coast Shelf Sc 2008;77:688-96. http://dx.doi.org/10.1016/j.ecss.2007.11.002.

Leston S, Nunes M, Viegas I, Lemos MFL, Freitas A, Barbosa J, et al. The effects of the nitrofuran furaltadone on Ulva lactuca. Chemosphere 2011;82:1010-6. http://dx.doi.org/ 10.1016/j. chemosphere.2010.10.067.

Leston S, Nunes M, Viegas I, Ramos F, Pardal MA. The effects of chloramphenicol on Ulva lactuca. Chemosphere 2013;91:552-7. http://dx.doi.org/10.1016/j. chemosphere.2012. 12.061.

Li DD, Lerman A, Mackenzie FT. Human perturbations on the global biogeochemical cycles of coupled $\mathrm{Si}-\mathrm{C}$ and responses of terrestrial processes and the coastal ocean. Appl Geochem 2011;26:S289-91. http://dx.doi.org/10.1016/j.apgeochem.2011.03. 084.

Li F, Bae M-J, Kwon Y-S, Chung N, Hwang S-J, Park S-J, et al. Ecological exergy as an indicator of land-use impacts on functional guilds in river ecosystems. Ecol Model 2013;252:53-62. http://dx.doi.org/10.1016/j.ecolmodel.2012.09.006.

Lillebø AI, Neto JM, Martins JM, Verdelhos T, Leston S, Cardoso PG, et al. Management of a shallow temperate estuary to control eutrophication: the effect of hydrodynamics on the system's nutrient loading. Estuar Coast Shelf Sci 2005;65:697-707. http://dx.doi.org/ 10.1016/j.ecss.2005.07.009.

Lira PK, Tambosi LR, Ewers RM, Metzger JP. Land-use and land-cover change in Atlantic Forest landscapes. For Ecol Manag 2012;278:80-9. http://dx.doi.org/ 10.1016/j.foreco.2012.05.008.

Lopes R. RIS - information sheet on Ramsar wetlands - Mondego Estuary. http://sites wetlands.org/reports/ris/3PT017_RISen06.pdf, 2006.

Lowicki D. Prediction of flowing water pollution on the basis of landscape metrics as a tool supporting delimitation of Nitrate Vulnerable Zones. Ecol Indic 2012;23:27-33. http://dx.doi.org/10.1016/j.ecolind.2012.03.004.

Lu D, Mausel P, Brondizios E, Moran E. Change detection techniques. Int J Remote Sens 2004;25(12):2365-407. http://dx.doi.org/10.1080/0143116031000139863.

Manandhar R, Odeh IOA, Pontius RG. Analysis of twenty years of categorical land transitions in the Lower Hunter of New South Wales, Australia. Agric Ecosyst Environ 2010;135:336-46. http://dx.doi.org/10.1016/j.agee.2009.10.016.

Marques JC, Nielsen SN, Pardal MA, Jørgensen SE. Impact of eutrophication and river management within a framework of ecosystem theories. Ecol Model 2003;166:147-68. http://dx.doi.org/10.1016/S0304-3800(03)00134-0.

Marques JC, Basset A, Brey T, Elliott M. The ecological sustainability trigon - a proposed conceptual framework for creating and testing management scenarios. Mar Pollut Bull 2009;58:1773-9. http://dx.doi.org/10.1016/j.marpolbul.2009.08.020. 
Moya V. Watershed delineation with MapWindow. Tutorial; 2011 [http://www. mapwindow.org].

Neary DG, Ice GG, Jackson CR. Linkages between forest soils and water quality and quantity. For Ecol Manag 2009;258:2269-81. http://dx.doi.org/10.1016/j.foreco.2009.05.027.

Nunes M, Marchand P, Vernisseau A, Le Bizec B, Ramos F, Pardal MA. PCDD/Fs and dioxin-like PCBs in sediment and biota from the Mondego estuary (Portugal). Chemosphere 2011;83:1345-52. http://dx.doi.org/10.1016/j.chemosphere.2011.02.081

O'Geen AT. Erodibility of agricultural soils, with examples in Lake and Mendocino Counties. Oakland: University of Calinfornia Division of Agriculture and Natural Resources; 2006. Publication 8194. http://anrcatalog.ucdavis.edu/pdf/8194.pdf.

OSGeo4W. Open source geospatial software for Win32 environments. Open Source Geospatial Foundation, 2012. http://trac.osgeo.org/osgeo4w/ Acessed 17-12-2012.

PBH do Rio Mondego. Síntese da Análise e Diagnóstico da Situação Actual. Enquadramento, vol. II. CCDR; 1998 [27 pp.].

Pinto R, Patrício J, Neto JM, Salas F, Marques JC. Assessing estuarine quality under the ecosystem services scope: ecological and socioeconomic aspects. Ecol Complex 2010;7: 389-402. http://dx.doi.org/10.1016/j.ecocom.2010.05.001.

Pontius RG, Millones M. Death to Kappa: birth of quantity disagreement and allocation disagreement for accuracy assessment. Int J Remote Sens 2011;32(15):4407-29. http://dx.doi.org/10.1080/01431161.2011.552923.

Pontius RG, Shusas E, McEachern M. Detecting important categorical land changes while accounting for persistence. Agric Ecosyst Environ 2004;101:251-68. http://dx.doi.org/ 10.1016/j.agee.2003.09.008

Puyravaud J-P. Standardizing the rate of deforestation. For Ecol Manag 2003;177:593-6. http://dx.doi.org/10.1016/S0378-1127(02)00335-3.

Ribeiro C, Pardal MA, Martinho F, Margalho R, Tiritan ME, Rocha E, et al. Distribution of endocrine disruptors in the Mondego River estuary, Portugal. Environ Monit Assess 2009;149:183-93. http://dx.doi.org/10.1007/s10661-008-0192-y.

Rojas C, Pino J, Basnou C, Vivanco M. Assessing land-use and -cover changes in relation to geographic factors and urban planning in the metropolitan area of Concepción (Chile). Implications for biodiversity conservation. Appl Geogr 2013;39:93-103. http://dx.doi.org/10.1016/j.apgeog.2012.12.007.

Salazar O, Hansen S, Abrahamsen P, Hansen K, Gundersen P. Changes in soil water balance following afforestation of former arable soils in Denmark as evaluated using the DAISY model. J Hydrol 2013;484:218-139. http://dx.doi.org/10.1016/j.jhydrol.2013.01.036.

Santos LHMLM, Araújo AN, Fachini A, Pena A, Delerue-Matos C, Montenegro MCBSM. Ecotoxicological aspects related to the presence of pharmaceuticals in the aquatic environment. J Hazard Mater 2010;175(1-3):45-95. http://dx.doi.org/10.1016/ j.jhazmat.2009.10.100

Tavares AO, Pato RL, Magalhães MC. Spatial and temporal land use change and occupation over the last half century in a peri-urban area. Appl Geogr 2012;34: 432-44. http://dx.doi.org/10.1016/j.apgeog.2012.01.009.

Trabucco A, Zomer RJ, Bossio DA, van Straaten O, Verchot LV. Climate change mitigation through afforestation/reforestation: a global analysis of hydrologic impacts with four case studies. Agric Ecosyst Environ 2008;126:81-97. http://dx.doi.org/10.1016/ j.agee.2008.01.015.

Versace VL, Ierodiaconou D, Stagnitti F, Hamilton AJ. Appraisal of random and systematic land cover transitions for regional water balance and revegetation strategies. Agric Ecosyst Environ 2008;123:328-36. http://dx.doi.org/10.1016/j.agee.2007.07.012.

Vidal-Dorsch DE, Bay SM, Maruya K, Snyder SA, Trenholm RA, Vanderford BJ. Contaminants of emerging concern in municipal wastewater effluents and marine receiving water. Environ Toxicol Chem 2012;31(12):2674-82. http://dx.doi.org/10.1002/etc.2004.

Wang B, Liu D, Liu S, Zhang Y, Lu D, Wang L. Impacts of urbanization on stream habitats and macroinvertebrate communities in the tributaries of Qiangtang River, China. Hydrobiology 2012;680:39-51. http://dx.doi.org/10.1007/s10750-011-0899-6.

Wang Y, Wang P, Bai Y, Tian Z, Li J, Shao X, et al. Assessment of surface water quality via multivariate statistical techniques: a case study of the Songhua River Harbin region, China. J Hydro Environ Res 2013;7:30-40. http://dx.doi.org/10.1016/ j.jher.2012.10.003.

Wiens JA. Riverine landscapes: taking landscape ecology into the water. Freshw Biol 2002;47:501-15. http://dx.doi.org/10.1046/j.1365-2427.2002.00887.x.

Zhang L, Dawes WR, Walker GR. Response of mean annual evapotranspiration to vegetation changes at catchment scale. Water Resour Res 2001;37:701-8. http://dx.doi.org/10.1029/2000WR900325.

Zhang L, Vertessy R, Walker G, Gilfedder M, Hairsine P. Afforestation in a catchment context. Understanding the impacts on water yield and salinityCSIRO Land and Water Science Report Number 01/07; 2007. [http://www.ewater.com.au/uploads/file/ Afforestation\%20in\%20catchments.pdf]

Zhao G, Bryan BA, King D, Luo Z, Wanf E, Song Z, et al. Impact of agricultural management practices on soil organic carbon: simulation of Australian wheat systems. Glob Chang Biol 2013;19:1585-97. http://dx.doi.org/10.1111/gcb.12145.

Zhou T, Wu J, Shaolin P. Assessing the effects of landscape pattern on river water quality at multiple scales: a case study of the Dongjiang River watershed, China. Ecol Indic 2012;23:166-75. http://dx.doi.org/10.1016/j.ecolind.2012.03.013. 